\title{
Intrinsic and extrinsic controls of spatial and temporal variations in modern fluvial tufa sedimentation: A thirteen-year record from a semi-arid environment
}

\author{
CONCHA ARENAS, MARTA VÁZQUEZ-URBEZ, LUIS AUQUÉ, CARLOS SANCHO, \\ CINTA OSÁCAR and GONZALO PARDO \\ Dpto. de Ciencias de la Tierra, Universidad de Zaragoza, C/Pedro Cerbuna 12, 50009 Zaragoza, Spain \\ (E-mail: carenas@unizar.es)
}

Associate Editor - Martyn Pedley

\begin{abstract}
Sedimentological and hydrochemical parameters of the River Piedra (northeast Spain) were monitored every six months (from 1999 to 2012) at 24 sites, at which tablets were installed all along the river. The river water is of $\mathrm{HCO}_{3}-\mathrm{SO}_{4}$-Ca type and is notably influenced by inputs from upstream karstic springs. Tufa deposition was first detected $8 \mathrm{~km}$ downstream of these springs and greatly increased from there, primarily along the steeper stretch (i.e. within the Monasterio de Piedra Natural Park); then, deposition decreased through the most downstream stretch, with smaller ground water inputs. The spatial evolution of the tufa thickness, with parallel variations of PWP (Plummer, Wigley, Parkhurst) rates, was thus determined by the river water $\mathrm{pCO}_{2}$ which was controlled by ground water inputs and by the river bed slope. Five fluvial subenvironments and seven sedimentary facies were characterized. The water flow conditions are the primary factor responsible for the distinct deposition rates of facies, mainly through $\mathrm{CO}_{2}$-outgassing. Stromatolites and moss-tufa and alga-tufa had the highest rates, whereas loose tufa formed in slow-flowing water and tufa of spray areas had thinner deposition. A six-month pattern in the deposition rate was detected through thickness measurements. That pattern was parallel to the seasonal PWP rates. The increased deposition during warm periods (spring and summer; mean: $5.08 \mathrm{~mm}$ ) compared with cool periods (autumn and winter; mean: $2.77 \mathrm{~mm}$ ) is linked chiefly to temperature, which controlled the seasonal changes in the physico-chemical and biological processes; this finding is supported by a principal components analysis. Seasonal variations of insolation and day duration also contributed to such a deposition pattern. Large discharge events, which provoked erosion of tufa deposits and dilution of water, caused the reversal of the seasonal deposition rate pattern. Stromatolites are likely to preserve the most complete sedimentary record. Although tufas are a potentially sensitive record of climate-related parameters, erosion is an intrinsic process that may overwhelm the effects of such parameters. This issue should be considered in palaeoclimatic studies based on the tufa record, particularly in semi-arid conditions.
\end{abstract}

Keywords Fluvial tufa facies, present hydrochemistry and deposition rate monitoring, sedimentary processes, semi-arid climate, Spain. 


\section{INTRODUCTION}

The study of present-day tufa sedimentation in the fluvial environment has become a matter of great interest because of the ability of tufas to record environmental (for example, climatic and hydrological) changes at different time scales. The high-deposition rates of fluvial tufas (i.e. as much as 16 to $17.5 \mathrm{~mm} \mathrm{yr}^{-1}$; Pentecost, 1978; Vázquez-Urbez et al., 2010) makes possible the short-term monitoring of physical, chemical and biological parameters, which allows the factors that control the tufa sedimentation to be analyzed. Most studies of present fluvial tufas deal with stable-isotope geochemistry (Hori et al., 2009; Kawai et al., 2009; Osácar et al., 2013), sedimentology (Drysdale \& Gillieson, 1997; Gradziński, 2010; Pedley \& Rogerson, 2010; Manzo et al., 2012) and hydrochemistry (Lorah \& Herman, 1988; Liu et al., 1995; Kano et al., 2003; Kawai et al., 2006; Auqué et al., 2013). Biological investigations, although much fewer in number, are also significant for understanding the role of organisms (for example, plants and prokaryotes) in tufa formation (Shiraishi et al., 2008; Pedley et al., 2009; Santos et al., 2010; Beraldi-Campesi et al., 2012), primarily through photosynthesis and extracellular polymeric substance (EPS) mediation (Arp et al., 2010; Pedley \& Rogerson, 2010; Shiraishi et al., 2010). Some geochemical studies of recent and ancient tufas have demonstrated that tufas are excellent archives of seasonal and interannual environmental conditions and, hence, tufas are considered to be high-resolution records (Lojen et al., 2004; Andrews, 2006; Brasier et al., 2010; Osácar et al., 2013). The textural and thickness variations of laminated tufas have also been used as indicators of short-term changes in environmental conditions (Kawai et al., 2009; Brasier et al., 2010). Most studies on existing systems are based on as much as two years of sedimentation and hydrochemical monitoring. In general, the aim of these studies was to explain the significance of variations in sedimentological, hydrochemical and geochemical parameters, mainly in terms of climate and hydrological interpretation.

This study includes sedimentological and hydrochemical analyses of a large number of monitored sites along the River Piedra (northeast Spain; a total of 24) that cover five main depositional sedimentary settings and were monitored every six months during a span of 13 years (from 1999 to 2012). Based on the data from such a long time series and on the large number of monitored sites along the river, the purpose of this study was to provide reliable patterns of variation in some sedimentological (i.e. type of sedimentary facies and their deposition rates) and hydrochemical characteristics of the fluvial tufa system through space and time, as well as to establish their relations to intrinsic (i.e. depositional environmental parameters, fluvial bed topography) and extrinsic factors (i.e. climate and hydrology parameters).

The results of this study not only confirm conclusions of a preliminary study performed in a shorter stretch of this river from 1999 to 2005 (Arenas et al., 2010; Vázquez-Urbez et al., 2010) but also make possible the discussion of sedimentological and hydrochemical variations over larger time and spatial scales, thus providing new and robust patterns. The results are therefore considered highly representative and can be of great significance to the sedimentological and climatic interpretation of ancient tufa systems, in particular within semi-arid conditions.

\section{LOCATION AND GENERAL BACKGROUND: GEOGRAPHY, GEOLOGY, CLIMATE AND HYDROLOGY}

The valley of the River Piedra is located in the central part of the Iberian Range, a north-west/ south-east trending Alpine intraplate fold belt. The River Piedra is a $41 \mathrm{~km}$ long, south to north flowing tributary of the River Jalón which, in turn, flows into the River Ebro (Fig. 1A). Its drainage area occupies some $1545 \mathrm{~km}^{2}$, and its altitude ranges from 600 to $1010 \mathrm{~m}$. The studied part of the river comprises the stretch from springs S1 and S2 in Cimballa to the La Tranquera reservoir ( $\mathrm{ca} 16.5 \mathrm{~km}$ long; Fig. 1B). Upstream of Cimballa, the River Piedra remains dry for most of the year. Along the studied stretch, the river flows through Jurassic limestones, Lower Cretaceous siliciclastic sands and sandstones, and a thick Upper Cretaceous sequence of limestones and dolostones. All of these units are slightly deformed by north-west/ south-east trending folds and faults. Tertiary detrital deposits overlie the sequence (Fig. 1B; Gabaldón et al., 1991). The river also flows across thick Quaternary tufaceous deposits distributed along the lower half of the studied stretch, and these deposits are thicker around the Monasterio de Piedra Natural Park (Arenas et al., 2004; Vázquez-Urbez et al., 2011, 2012). 

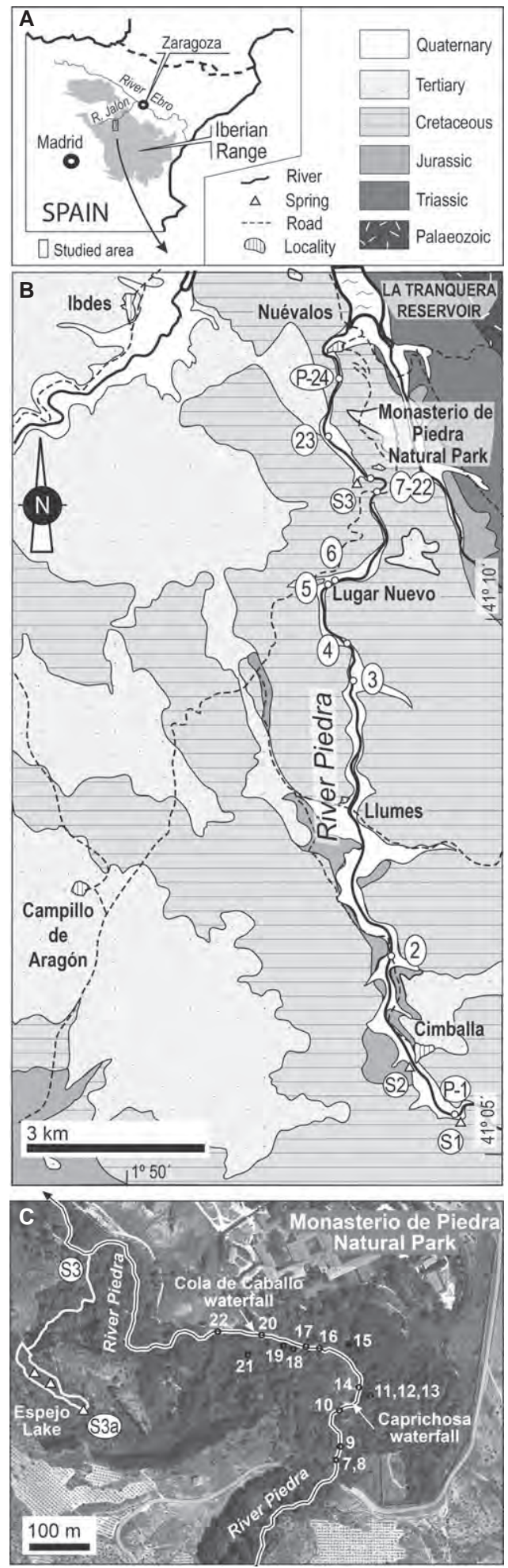

Fig. 1. Location of the River Piedra (A) and its geological context (B). (B) Location of sites monitored along the river (P-1 to $\mathrm{P}-24$ ) and of springs (S). The gauging point is at site P-23. (C) Detailed location of the studied sites within the Monasterio de Piedra Natural Park. S1, S2 and S3a are the springs monitored in this study. S3 refers to all ground water inputs from the lake to the river.
The climate of the area is continental Mediterranean with strong seasonal contrasts (cold semiarid climate). The annual mean temperature is $13 \cdot 1^{\circ} \mathrm{C}$, and the annual mean rainfall is $397.4 \mathrm{~mm}$ [averaged from the La Tranquera and Milmarcos meteorological stations, approximately $700 \mathrm{~m}$ and $1050 \mathrm{~m}$ above sea-level (m a.s.l.), respectively], for October 1999 to September 2012. The precipitation is irregularly distributed, with maxima in April/May and October (Fig. 2).

The River Piedra is fed mainly by water from an aquifer in the Lower Jurassic and Upper Cretaceous limestones and dolostones that are approximately $500 \mathrm{~m}$ thick (Servicio Geológico de Obras Públicas, 1990). The most important natural springs are near Cimballa (Fig. 1; for example, S1 and S2, with a mean discharge of $1.4 \mathrm{~m}^{3} \mathrm{~s}^{-1}$; data from Confederación Hidrográfica del Ebro, https://195·55·247.237/saihebro). Additional inputs originate from the springs that feed the Espejo Lake (hereafter referred to as S3, with a mean discharge of approximately $0.81 \mathrm{E}-03 \mathrm{~m}^{3}$ $\mathrm{s}^{-1}$ ) at the lower part of the Natural Park; the lake water enters the river downstream of the main knickpoints (Fig. 1C). The mean annual discharge of the River Piedra was approximately $1.06 \mathrm{~m}^{3} \mathrm{~s}^{-1}$ for October 1999 to September 2012 (gauging point at site P-23; Fig. 1B). The monthly discharge followed an approximate cyclical pattern with a low amplitude due to the strong influence of the ground water supply (Fig. 3A). The maximum values were measured during winter and the minimum values were measured during summer. However, this trend was disturbed by flood events related to heavy rains; these usually occurred in May (for example, an instantaneous discharge of $30 \mathrm{~m}^{3} \mathrm{~s}^{-1}$ in May 2004) but also occasionally during the autumn (for example, an instantaneous discharge of $25 \mathrm{~m}^{3} \mathrm{~s}^{-1}$ in November 2008; Fig. 3B).

The Quaternary incision of the River Piedra created a fluvial valley with strong topographical discontinuities controlled by tectonics and changes in the bedrock lithology that favoured tufa deposition from the Pleistocene to present. The resulting stepped valley hosts Quaternary tufa deposits distributed along the lower half of the studied area (Fig. 4; Sancho et al., 2010; Vázquez-Urbez et al., 2011, 2012).

The longitudinal profile of the River Piedra at present (Fig. 4) shows a $224 \mathrm{~m}$ change in altitude from the springs at Cimballa $(916 \mathrm{~m})$ to the entrance at the La Tranquera reservoir $(692 \mathrm{~m})$. The main knickpoints are located at Lugar Nuevo and within the Natural Park. Some large 


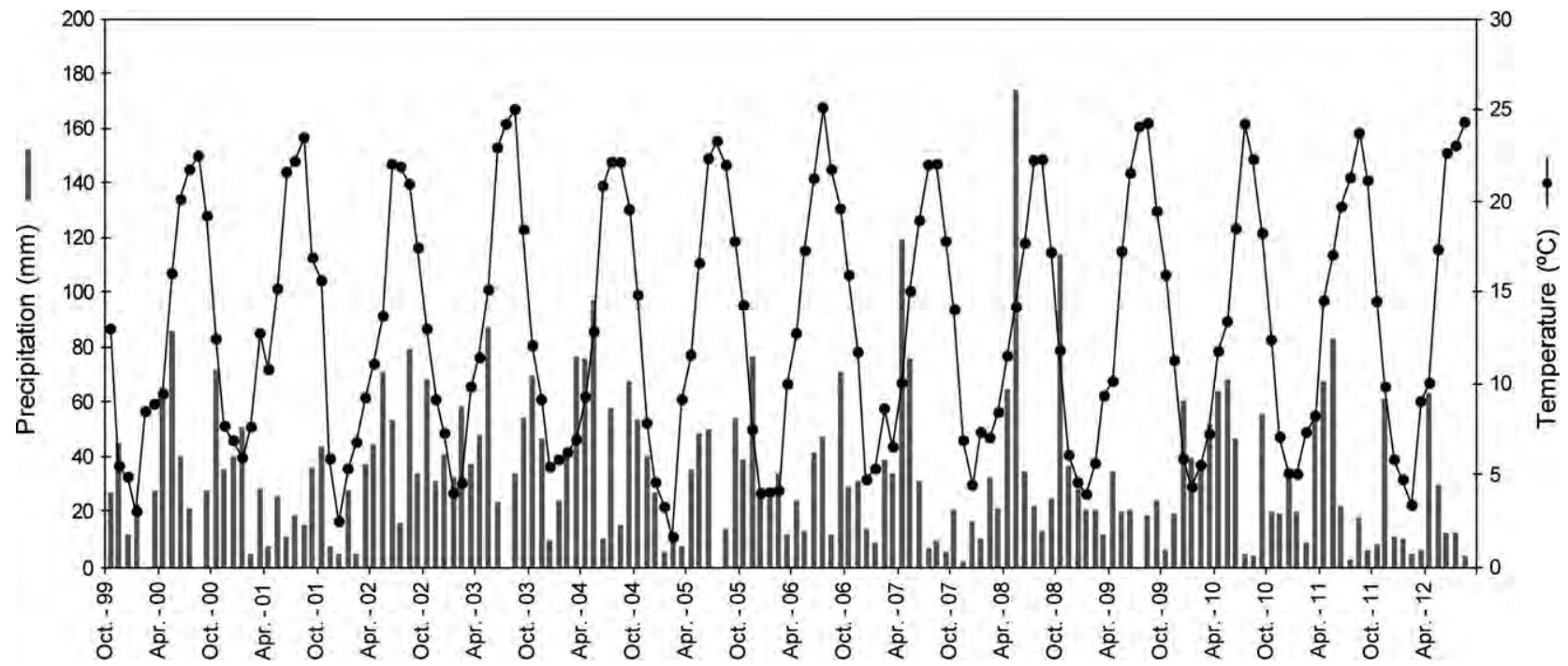

Fig. 2. Mean monthly air temperature and precipitation from 1999 to 2012. Data from the meteorological stations of La Tranquera and Milmarcos (Milmarcos is $8.69 \mathrm{~km}$ to the west of Cimballa; Fig. 1) provided by the Agencia Estatal de Meteorología, Spain.
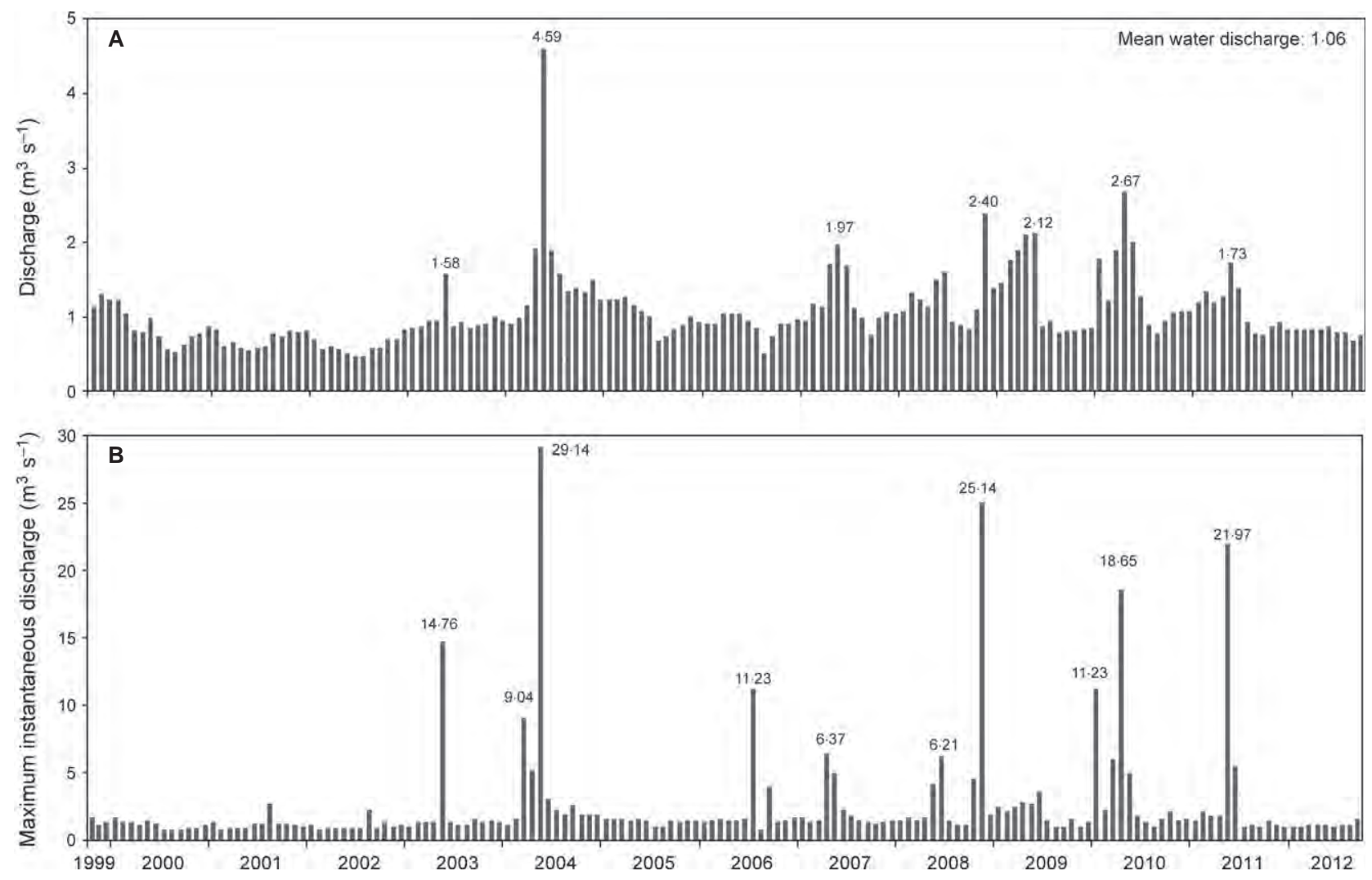

Fig. 3. Monthly distribution of discharge (A) and maximum instantaneous discharge (B) from 1999 to 2012. Data from the Nuévalos gauging point (site P-23; Fig. 1), provided by the Confederación Hidrográfica del Ebro, Spain.

waterfalls are observed in these areas; La Requijada, at Lugar Nuevo, is a waterfall ca $12 \mathrm{~m}$ high and, within the park, the Caprichosa and Cola de Caballo waterfalls are $\mathrm{Ca} 15 \mathrm{~m}$ and $35 \mathrm{~m}$ high, respectively. Upstream and downstream of those knickpoints, the river slope is much more gradual (Fig. 4).

Within the Natural Park, a complex water-flow arrangement can be observed, and it consists of a multichannel system formed by stepped water- 


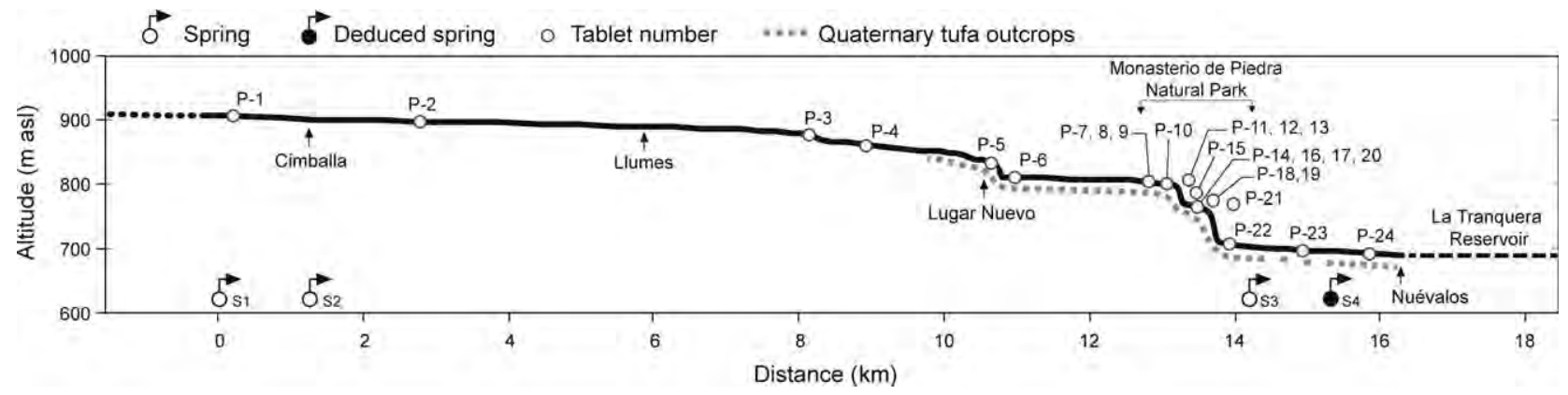

Fig. 4. Topographical profile and location of monitoring sites along the River Piedra. The numbers correspond to monitored sites with tablets and hydrochemistry sampling. Springs are also indicated.

falls, vertical waterfalls, pools and caves, partially influenced by human action. Within this arrangement, present-day tufas are being deposited at varied, but generally high, rates (Vázquez-Urbez et al., 2010).

\section{METHODS}

From November 1999 to September 2012, sedimentological and hydrological characteristics were monitored once every six months at 24 sites from the headwaters of the River Piedra in Cimballa to the La Tranquera Reservoir, representing different subenvironments of the river (except vertical waterfalls). These fluvial subenvironments were mostly defined by physical flow characteristics, the morphological features of the river bed and sediment components (see below, Sedimentological characteristics of the River Piedra). Springs S1, S2 and S3a were also sampled for a study on their hydrochemistry (Fig. 1).

\section{Monitoring of deposition rates and sediment characteristics}

At the selected sites, a total of 24 limestone tablets $(25 \times 16 \times 2 \mathrm{~cm})$ were installed parallel to the floor, although the number of tablets varied through time (see Table 2). These tablets were removed at the end of March and September for a six-month measurement of sediment thickness. After the measurement, they were returned to their original position until the following semester. The differences in sediment thickness between consecutive measurements represent the six-month accumulation rates for each site. The measurement device used is similar to the microerosion meter (MEM) designed by Drysdale \& Gillieson (1997). The details of the procedure were described by Vázquez-Urbez et al. (2010). In the present study, spring and summer is considered the warm period, and autumn and winter is considered the cool period, hereafter referred to as 'warm' and 'cool', respectively.

During the 13 year monitoring, each group of tablets was replaced with new ones after three to four years as a result of thick accumulation and the inability of the MEM to make additional measurements in some of them. Once removed, the tablets were cut perpendicular to the accumulation surface, and the six-month intervals were identified on the cross-sections by plotting the successive measurements taken through the MEM on the corresponding raw cuts. Then, thin sections of the tablets were made for the textural analysis in the optical microscope. Samples were also collected for an analysis by scanning electron microscopy using a JEOL JSM 6400 (JEOL Limited, Tokyo, Japan) and a Carl Zeiss MERLIN $^{\mathrm{TM}}$ (Carl Zeiss Group, Jena, Germany). Thin sections and SEM analysis were performed at the Servicio de Apoyo a la Investigación (SAI) facilities of the University of Zaragoza. Once ground and sieved (sieve mesh opening: $53 \mu \mathrm{m}$ ), the sediment mineralogy of some tablets was determined by X-ray diffraction using a Phillips PW 1729 diffractometer (Phillips Analytical, Almelo, Netherlands) of the Cristallography and Mineralogy Division of the University of Zaragoza. The samples invariably consisted of low-Mg calcite with minor amounts of detrital phyllosilicates, quartz and occasional dolomite.

\section{Flow dynamics, water sampling, water analyses and geochemical calculations}

The flow dynamics were characterized from water flow velocity (through a surface velocity meter) and depth measurements taken at the end of the four seasons. The water discharge 
data were obtained from the Nuévalos gauging point, controlled by the Confederación Hidrográfica del Ebro. The water samples for the chemical analysis were taken along the River Piedra from the sites indicated in Figs 1 and 4. The sampling was performed biannually (in the middle of the warm and cool periods; i.e. at the end of December or beginning of January and at the end of June, from 1999 to 2012). In addition, continuous recording of water temperature was conducted from July 2007 onwards by means of two temperature recorders (HOBO Pro V2; Onset, Cape Cod, Massachussets, USA) installed at sites P-8 and P-22.

The conductivity, temperature and $\mathrm{pH}$ were measured on-site using a portable conductivity meter (Jenway 4200; Bibby Scientific Limited, Stone, UK) and a portable $\mathrm{pH}$ meter (Orion 250A; Argus-Hazco, Chesterfield, Michigan, USA). At the same time, water samples were collected at those sites for chemical determinations (i.e. alkalinity, $\mathrm{Cl}, \mathrm{SO}_{4}, \mathrm{Ca}, \mathrm{Mg}, \mathrm{Na}$ and $\mathrm{K}$ ). The water analyses were performed at the Petrology and Geochemistry Laboratory of the University of Zaragoza. The sampling and analytical methodologies are described in VázquezUrbez et al. (2010) and Auqué et al. (2013). In the present study, the percentage of charge imbalance for the analytical data was always $<10 \%$ (as calculated with the PHREEQC code; see below) and, for $92 \%$ of samples, was $<5 \%$ (out of a total of 315 samples).

The speciation-solubility calculations to obtain calcite saturation index (SIc), total dissolved inorganic carbon (TDIC) and partial pressure of $\mathrm{CO}_{2}$ values of water samples were performed with the PHREEQC code (Parkhurst \& Appelo, 1999) and the WATEQ4F thermodynamic database (Ball \& Nordstrom, 2001) supplied with it.

The inorganic precipitation rate for calcite (in $\mathrm{mmol} \mathrm{cm} \mathrm{cm}^{-2} \mathrm{~s}^{-1}$ ) was calculated using the rate law of Plummer et al. (1978), frequently known as the PWP (Plummer, Wigley, Parkhurst) rate equation:

$$
\begin{aligned}
\mathrm{PWP}= & -\kappa_{1} \mathrm{aH}^{+}-\kappa_{2} \mathrm{aH}_{2} \mathrm{CO}_{3}^{*}-\kappa_{3} \mathrm{aH}_{2} \mathrm{O} \\
& +\kappa_{4} \mathrm{aCa}^{2+} \mathrm{aHCO}_{3}^{-}
\end{aligned}
$$

where $\mathrm{H}_{2} \mathrm{CO}_{3}{ }^{*}=\mathrm{H}_{2} \mathrm{CO}_{3}+\mathrm{CO}_{2(\text { aq })}$ and $\kappa_{1}, \kappa_{2}, \kappa_{3}$ and $\kappa_{4}$ are the empirically determined rate constants. The temperature functions proposed by Plummer et al. (1978) and Kaufmann \& Dreybrodt (2007) for the rate constants are used. Activity values for the involved (dissolved) species $\left(\mathrm{aH}^{+}\right.$, $\mathrm{aH}_{2} \mathrm{CO}_{3}{ }^{*}, \mathrm{aCa}^{2+}, \mathrm{aH}_{2} \mathrm{O}$ and $\mathrm{aHCO}_{3}{ }^{-}$) are also cal- culated with the PHREEQC code (Parkhurst \& Appelo, 1999). Equation 1 has been used frequently in tufa-depositing streams (Lorah \& Herman, 1988; Dreybrodt et al., 1992; Liu et al., 1995; Kano et al., 2003, 2007; Kawai et al., 2006, 2009; Shiraishi et al., 2008) because it provides the maximum rate of inorganic precipitation in turbulent water (Dreybrodt \& Buhmann, 1991).

\section{Principal components analysis}

Principal components analysis (PCA; Davis, 2002) was used for the data reduction and deciphering patterns in a large set of physicochemical data constituted by water analyses, water velocity and other variables measured at the sampling sites during all of the monitored periods. The results of a PCA are usually discussed in terms of component loadings (a measure of the relative importance of each original variable on the calculated principal components) and scores (the projection of each data point in the PC space). In this study, the PC scores for each data point were plotted, and the plots were visually inspected for clustering and similarities with the aid of BiPLot (a visualization of the PCA loadings showing a projection of the original variables onto the scattergram; Hammer, 2010). The PCA was applied to the correlation matrix to ensure that the elements in the analysis were weighted equally. The free statistical software package Past v. 2.03 (Hammer, 2010; http://folk.uio.no/ohammer/past/index. html) was used for the PCA calculations.

\section{SEDIMENTOLOGICAL CHARACTERISTICS OF THE RIVER PIEDRA}

The examination of the morphological features of the river bed, physical flow characteristics (i.e. water velocity and depth), sediment components (for example, floral and bacterial associations) and other texture and structure features revealed five fluvial subenvironments, plus those of vertical waterfalls and caves, which could be distinguished (Table 1; Figs 5 to 8). Of these, the large vertical waterfalls were not monitored in this study because of the difficultly in accessing them, and caves are not considered here because of their different environmental context. A total of seven sedimentary facies were characterized through the periodical monitoring (Table 1; Figs 5 to 8). 


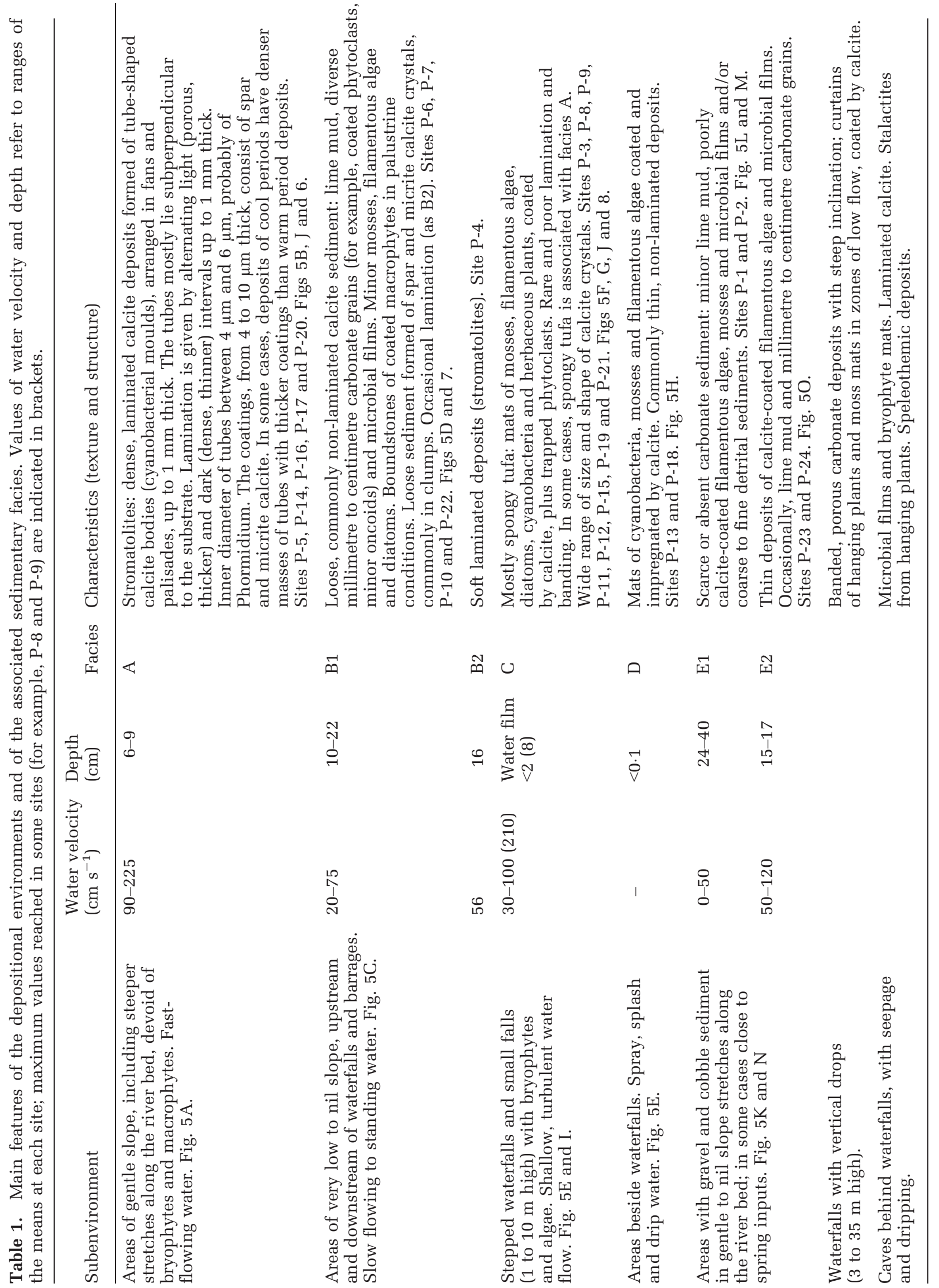



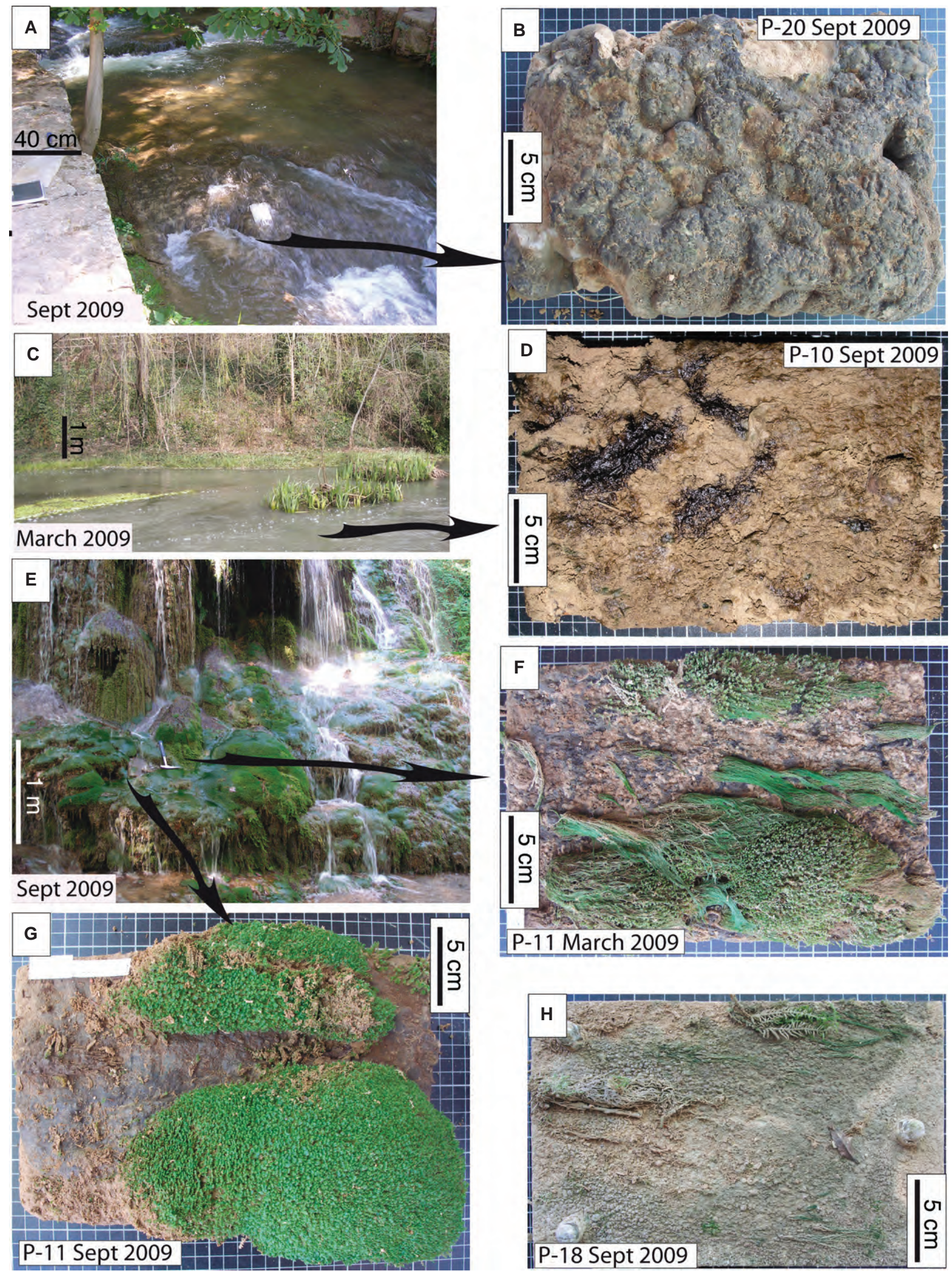

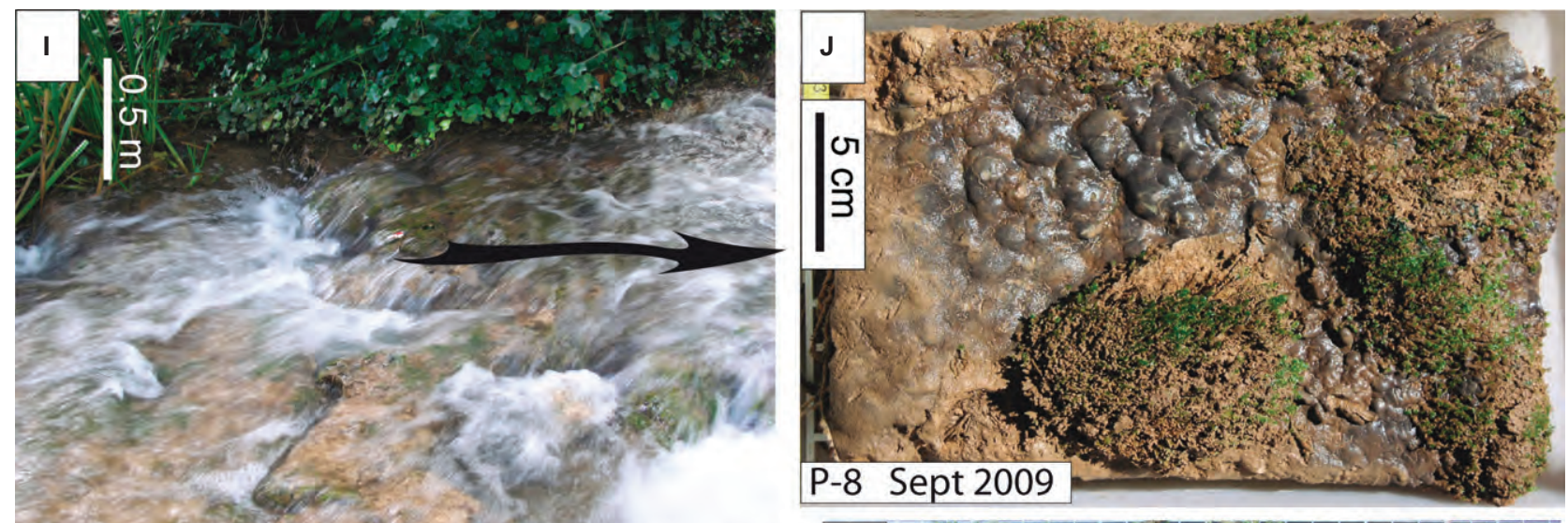

Sept 2009
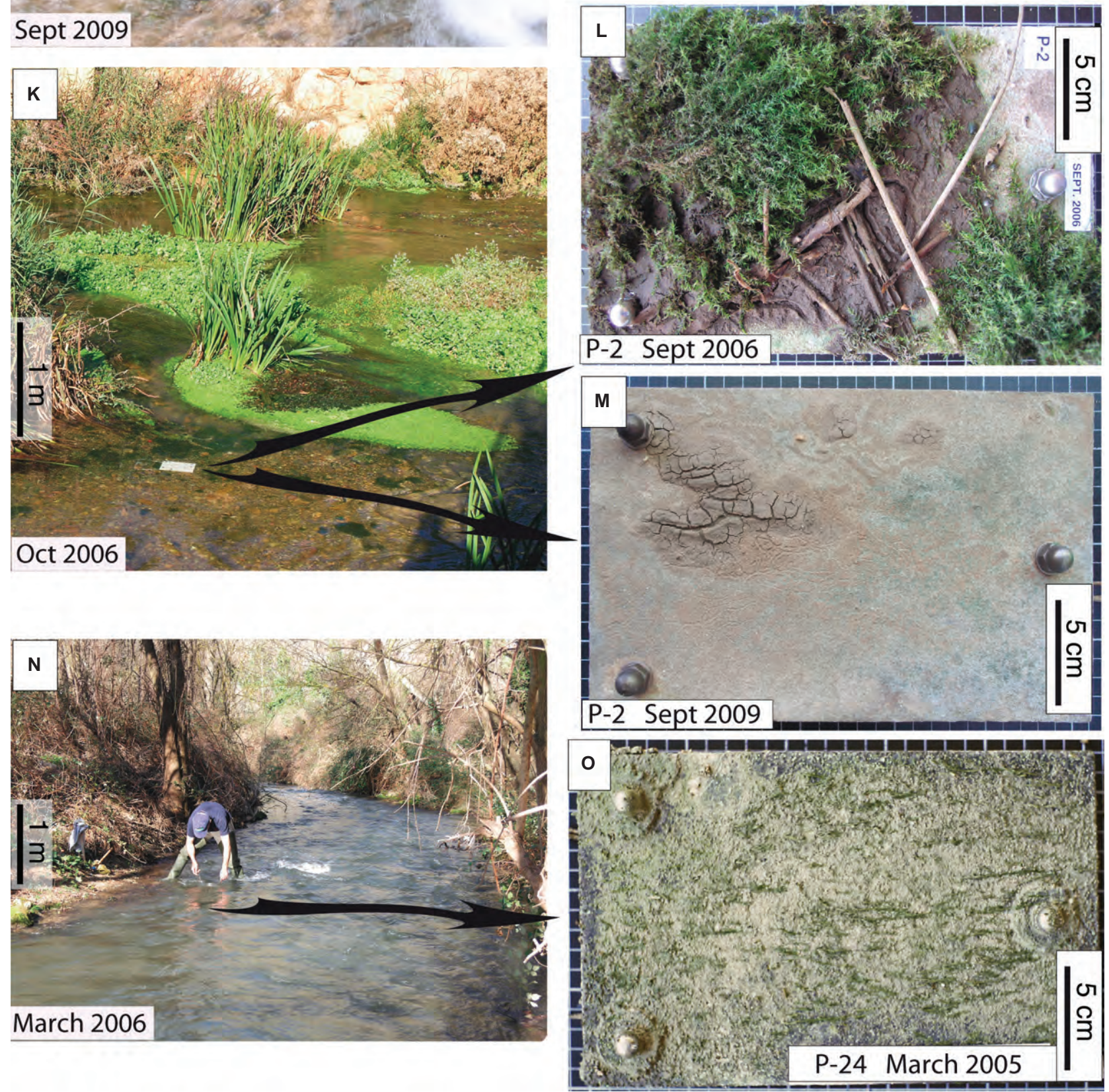
Fig. 5. Field views of the different fluvial subenvironments and of sediment deposited on tablets (plan views). (See Table 1 for facies characteristics.) (A) and (B) Fast-flowing water areas and facies A (stromatolites). (C) and (D) Slow-flowing water areas and facies B (soft, loose sediment). (E), (F) and (G) Stepped waterfalls with facies C (coated mosses, algae and bacterial mats; note the cyanobacterial hemispherical bodies). (H) Bacterial mats, filamentous algae and mosses from spray and splash areas. (I) and (J) Small jumps with facies A and C. Note the cyanobacterial mat associated with mosses in (K), (L) and (M) Slow-flowing water areas and facies E1 (poorly calcitecoated mosses and detrital sediment made of sand-sized particles and plant fragments). (N) and (O) Fast flowing water areas and facies E2 (thin deposit of filamentous algae and bacterial mats).

The textural analysis of samples in optical and scanning electron microscopes showed that the deposits are composed of calcite coatings over biological substrates (for example, grasses, mosses, algae and cyanobacteria that later decayed), calcite-impregnated biological substrates (for example, cyanobacterial filaments and mucus) and clumps of calcite grains as much as $1 \mathrm{~mm}$ long (Table 1). The matrix among these components is usually a heterogeneous mass of single and composite calcite crystals and tufa fragments. This analysis allowed some differences to be distinguished between sediment deposited in warm and in cool periods. However, these differences were not always clear and varied among the types of facies, as indicated in a preliminary study (Vázquez-Urbez et al., 2010). In general, spar and micrite calcite with varied crystal shapes compose the sediment of both the warm and cool periods, although larger crystals tend to be more abundant in some deposits of the cool periods. In some cases, facies A (stromatolites; Fig. 6A) showed less dense tubemade fabrics in the deposits of the warm periods (Fig. 6B, C and D). These tubes are thinner (cortices 4 to $7 \mu \mathrm{m}$ thick) than those of cool periods (cortices 6 to $10 \mu \mathrm{m}$ thick; Fig. 6E, F and G). However, calcite coatings of similar thickness were observed in the tubes of both periods. Diatoms were more abundant in the sediment of warm periods, in particular in facies B and C (Figs 7C and 8C). The porosity from insect larvae and annelids commonly appeared in the warm period deposits. Coated and uncoated leaves and other plant remains, as well as their empty moulds, were more abundant at the base of the cool period intervals.

\section{HYDROGEOCHEMISTRY OF THE RIVER PIEDRA}

The River Piedra waters are of the $\mathrm{HCO}_{3}-\mathrm{Ca}$ type with low $\mathrm{Cl}$ contents during all of the monitored periods. However, the samples are widely distributed along the $\mathrm{HCO}_{3}$-Ca field in the Piper diagram (Fig. 9), from a clearly dominant $\mathrm{HCO}_{3}$ type at the headwater springs towards an $\mathrm{HCO}_{3}-$ $\mathrm{SO}_{4}$ type at the rest of the examined stretch (including the Natural Park). Thus, a wide variability can be observed in some hydrochemical parameters: conductivity values range from 274 to $734 \mu \mathrm{S} \mathrm{cm}^{-1}$, alkalinity ranged from 200 to $372 \mathrm{mg} \mathrm{L}^{-1}$, Ca ranged from 61 to $112 \mathrm{mg} \mathrm{L}^{-1}$ and $\mathrm{SO}_{4}$ ranged from $9 \cdot 25$ to $157.5 \mathrm{mg} \mathrm{L}^{-1}$.

This apparent variability is mainly associated with: (i) the distinctive chemical characteristics of River Piedra waters at site P-1 (Fig. 9A), where the lowest conductivity, $\mathrm{Ca}$ and $\mathrm{SO}_{4}$ values and the highest alkalinity values were measured; and with (ii) the existence of some 'dilution events', such as the one recorded in January 2010 at the Natural Park (Fig. 9B), which was associated with the unusually high discharge and flood peaks measured that month (Fig. 3) and led to a general decrease in the conductivity, alkalinity, $\mathrm{Ca}$ and $\mathrm{SO}_{4}$ of the waters with respect to those usually measured in the Natural Park.

The River Piedra waters between sites P-2 and P-24 (Fig. 4) are distributed in the same compositional field of the Piper diagram (except for the aforementioned sampling in January 2010; Fig. 9A and B), and they show more homogeneous chemical characteristics (conductivity from 503 to $734 \mu \mathrm{S} \mathrm{cm}{ }^{-1}$; alkalinity from 238 to $350 \mathrm{mg} \mathrm{L}^{-1}$; Ca from 75 to $112 \mathrm{mg} \mathrm{L}^{-1}$; and $\mathrm{SO}_{4}$ from 54 to $157 \mathrm{mg} \mathrm{L}^{-1}$ ). The differences in the chemical characteristics between site P-1 and the rest of the sampling points are linked to the influence of different ground water inputs: the water composition at site P-1 is controlled by spring $\mathrm{S} 1$, whereas the greater discharge of spring S2 (from $0 \cdot 8$ to $2.2 \mathrm{~m}^{3} \mathrm{~s}^{-1}$; data from Confederación Hidrográfica del Ebro) dominates the chemical composition of the River Piedra downstream (Figs 4, 9A and 9C). The contribution of spring S3 downstream of site P-22 (Fig. 4), with overall compositional characteristics similar to 

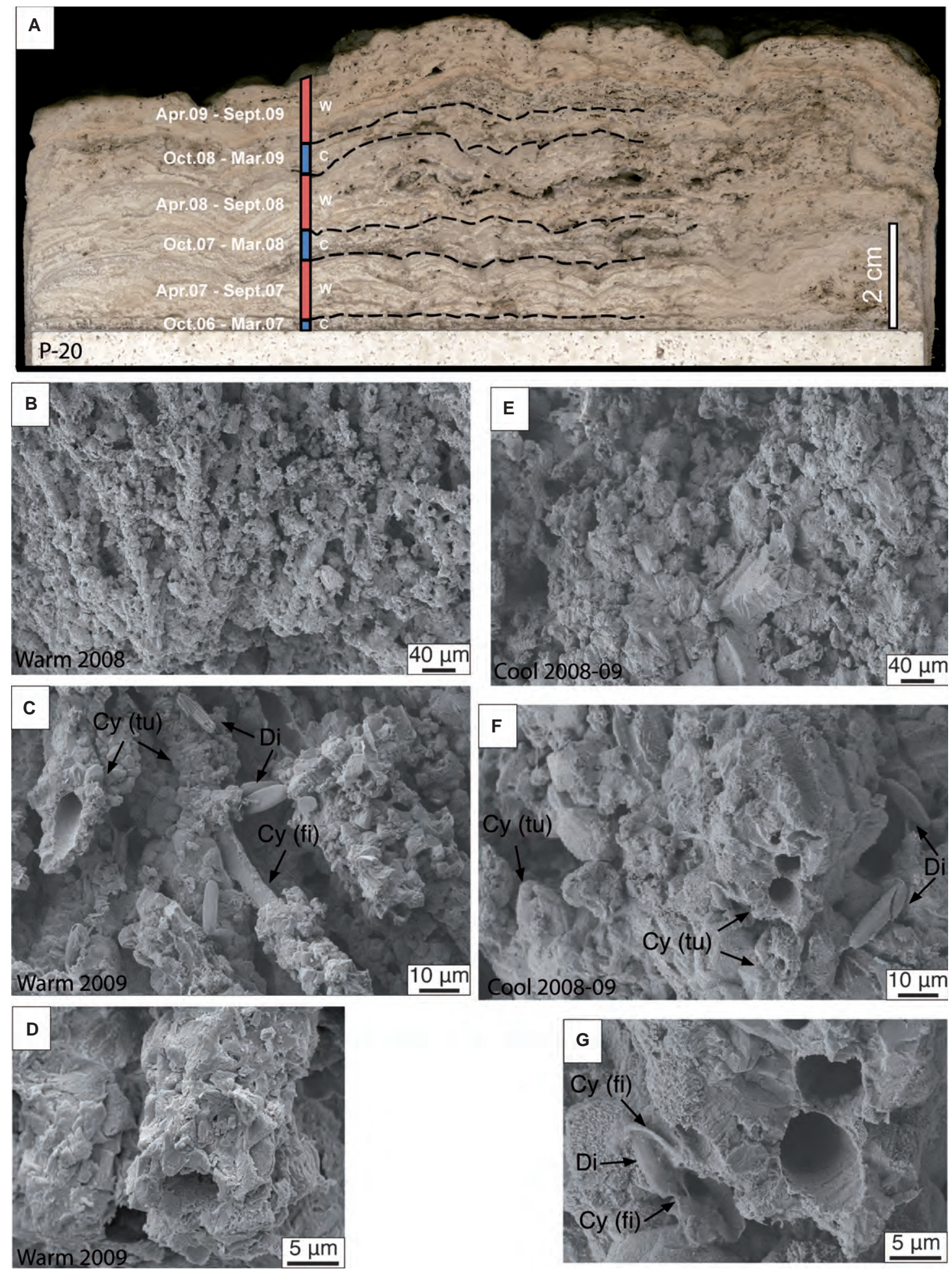

Fig. 6. Facies A: Stromatolites. (A) Cross-section of tablet P-20 (see Fig. 5B) perpendicular to flow direction with an indication of six-month intervals identified through measures with the microerosion meter (MEM). (B) to (G) Images from SEM. (B), (C) and (D) Deposits of Warm 2008 and 2009. (B) Palisade made of calcite tubes perpendicular to oblique respect to substrate. (C) Detail of calcite coatings formed around filamentous cyanobacteria. Most are preserved as tubes - Cy (tu) - made of micrite calcite crystals. Note preserved calcified filament - Cy (fi) - in the middle. (D) Detail of calcite tubes. (E), (F) and (G) Deposits of Cool 2008-09. (E) Dense mass of calcite tubes. Note the presence of large crystals among tubes. (F) Detail of (E). (G) Detail of (F); calcite tubes, cyanobacterial filaments and diatoms. Cy (tu): Coating casts (tubes) from filamentous cyanobacteria. Cy (fi): Calcified cyanobacterial filament. Di: Diatoms. 

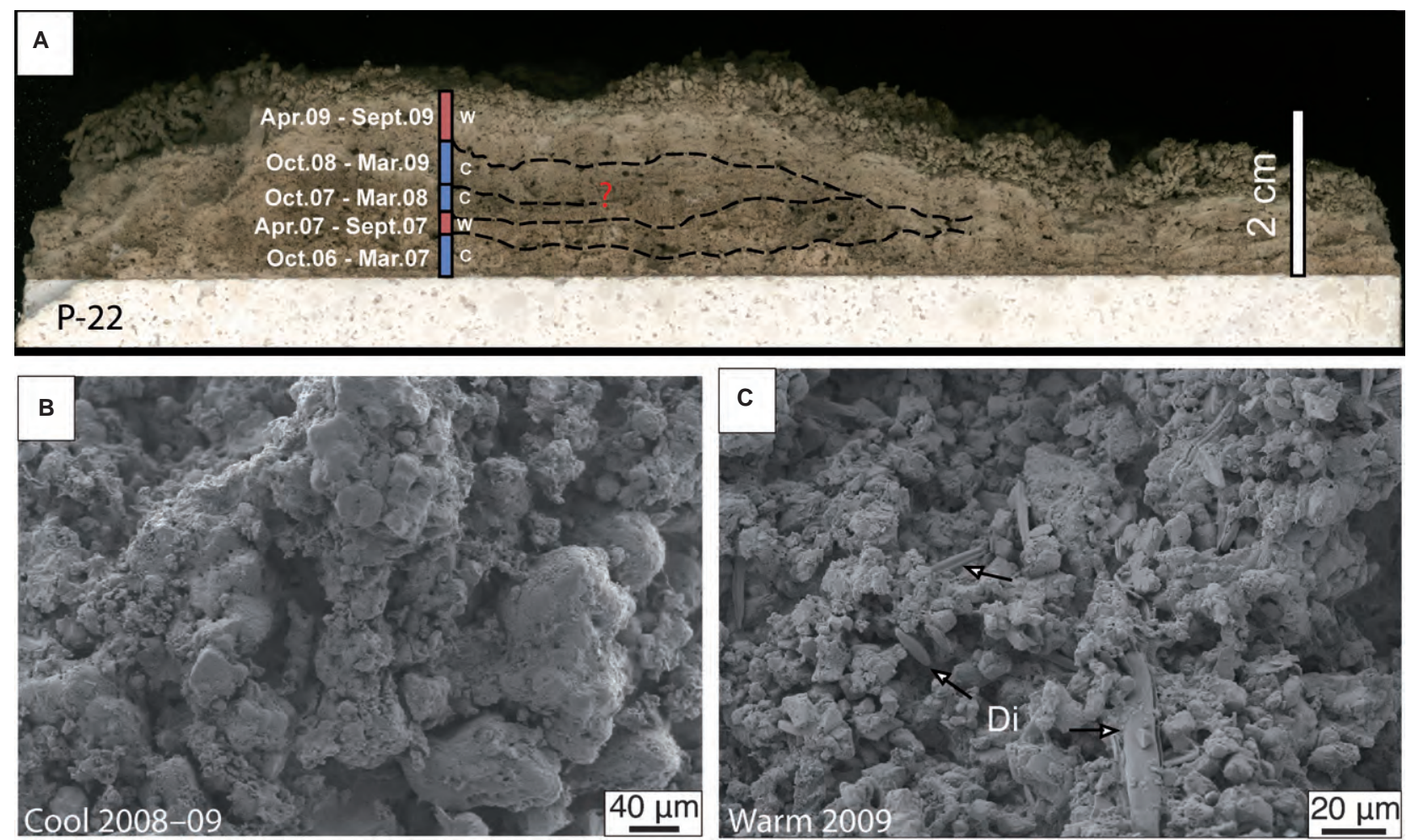

Fig. 7. Facies B: Loose, non-laminated tufa deposits. (A) Cross-section of tablet P-22 perpendicular to flow direction with an indication of six-month intervals identified through measures with the MEM. Note the absence of sediment record of the Warm 2008 and that sediment of the Warm 2009 deposited over an erosional surface affecting deposits of four periods. The latest deposit is made up of calcite-coated filamentous algae. (B) Deposit of Cool 2007-08. Note the presence of clumps. (C) Deposit of Warm 2009. Note the abundance of diatoms 'Di'.

those of spring S2, is more clearly observed in the plots discussed below.

\section{Spatial trends}

The evolution of the hydrochemical characteristics of the River Piedra exhibits distinct spatial trends during all of the monitored periods. The profiles of the major parameters showing the mean yearly values and the mean values for the cool and warm periods are summarized in Fig. 10.

At sites P-1 and P-2 (Fig. 4), the chemical characteristics of the river waters are strongly affected by the inputs of the nearby springs (S1 and S2) at equilibrium or near equilibrium with respect to calcite. The lowest $\mathrm{pH}$, SIc and PWP values and the highest $\mathrm{pCO}_{2}$ values throughout the studied stretch were recorded in this area for each sampling period (Fig. 10). The low SIc in the river waters, usually below $+0 \cdot 5$, agrees with the absence of tufa sedimentation in this stretch (see Table 2).

At site P-3, approximately $6 \mathrm{~km}$ downstream of site P-2 (Fig. 4), a clear jump in the SIc, pH and
PWP values, which was associated with a marked decrease in the $\mathrm{pCO}_{2}$ and $\mathrm{Ca}$ contents, was detected (Fig. 10). All of these characteristics suggest that tufa precipitation was already active at this site, in agreement with the sediment deposited on tablet P-3 (Table 2; Fig. 12).

From site P-3 to P-22 (Fig. 4), the SIc and PWP values remained relatively constant, usually with higher values in the warm than in the cool periods (Fig. 10), as was also the trend with the $\mathrm{pH}$ values. At the same time, a relatively continuous downstream decrease in alkalinity and Ca contents was detected both in the warm and in the cool periods (Fig. 10). At site P-6, this decreasing trend is broken due to the return of diverted flow into the river for hydroelectric power generation. All of these observations suggest that tufa formation is a continuous process between those sites, in agreement with the rates recorded in the tablets located there.

From site P-22 to P-24, continuous increases in temperature, conductivity, alkalinity and Ca (Fig. 10) were observed, promoted by the spring S3 inputs and, probably, by additional unknown 

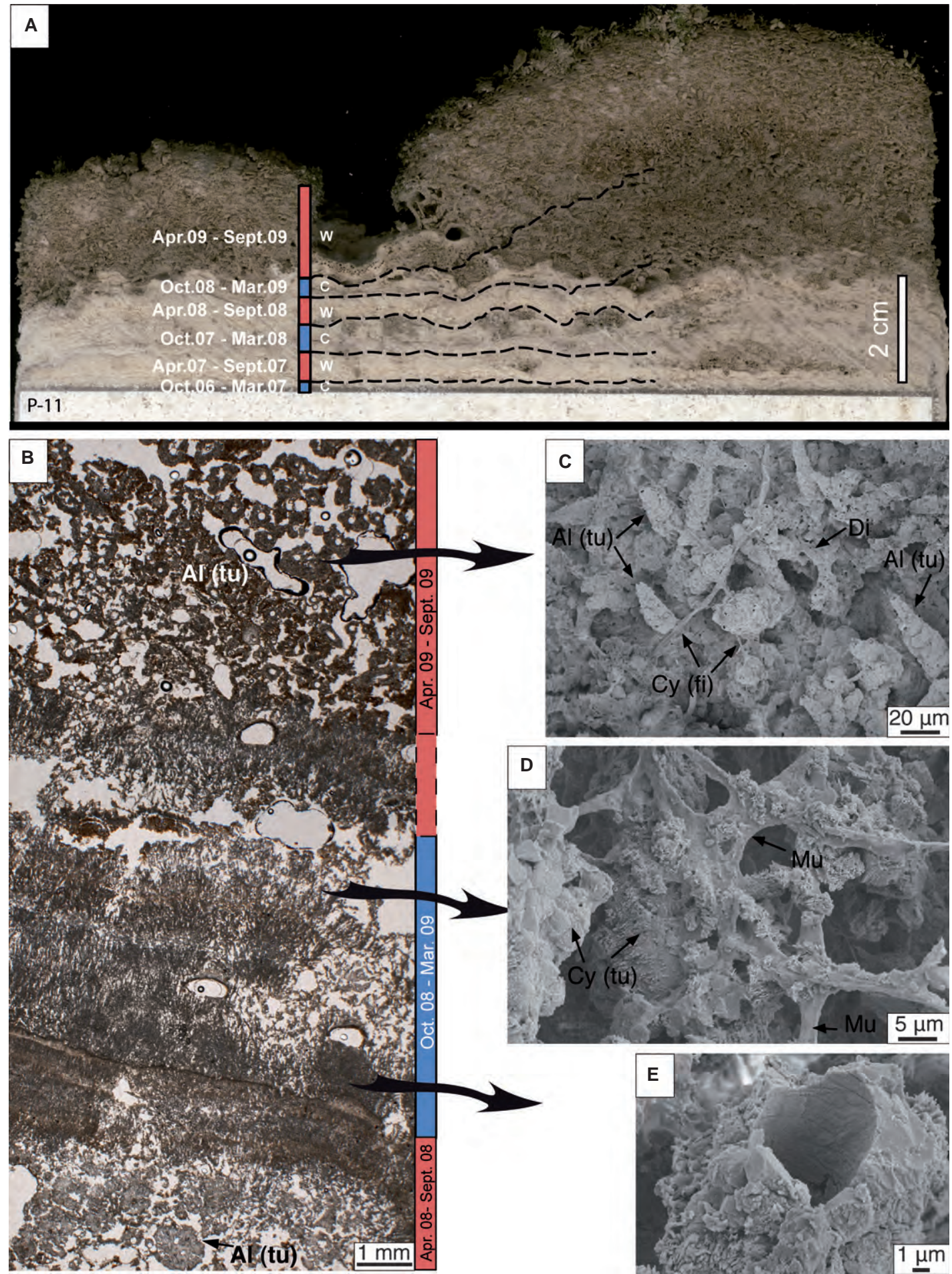

Fig. 8. Facies C and A: Spongy tufa made of mosses, algae and cyanobacterial laminae. (A) Cross-section of tablet P-11 (see Fig. 5G) perpendicular to flow direction, with an indication of six-month intervals identified through measures with the MEM. Note that the coated-moss deposits are better preserved in the last period; younger deposits are mainly formed of stromatolites, and minor boundstones formed of mosses and algae. (B) Boundstone of tubes (cross-sections) formed around algae - Al (tu) - deposited in the warm periods 2008 and 2009 . Laminae of micrite filamentous bodies (cyanobacteria) grew from the end of Warm 2008 to the beginning of Warm 2009. (C) Boundstone of algal tubes, cyanobacteria and diatoms. (D) Detail of cyanobacterial tubes, mucus extracellular polymeric substances (EPS) and diatoms. (E) Detail of a calcite coating around a filamentous cyanobacteria (decayed). Cy (tu) and Al (tu): Coating casts (tubes) from filamentous cyanobacteria and algae. Cy (fi): Calcified cyanobacterial filament. Di: Diatoms. Mu: Mucus (EPS).

(C) 2013 The Authors. Journal compilation (C) 2013 International Association of Sedimentologists, Sedimentology, 61, 90-132 


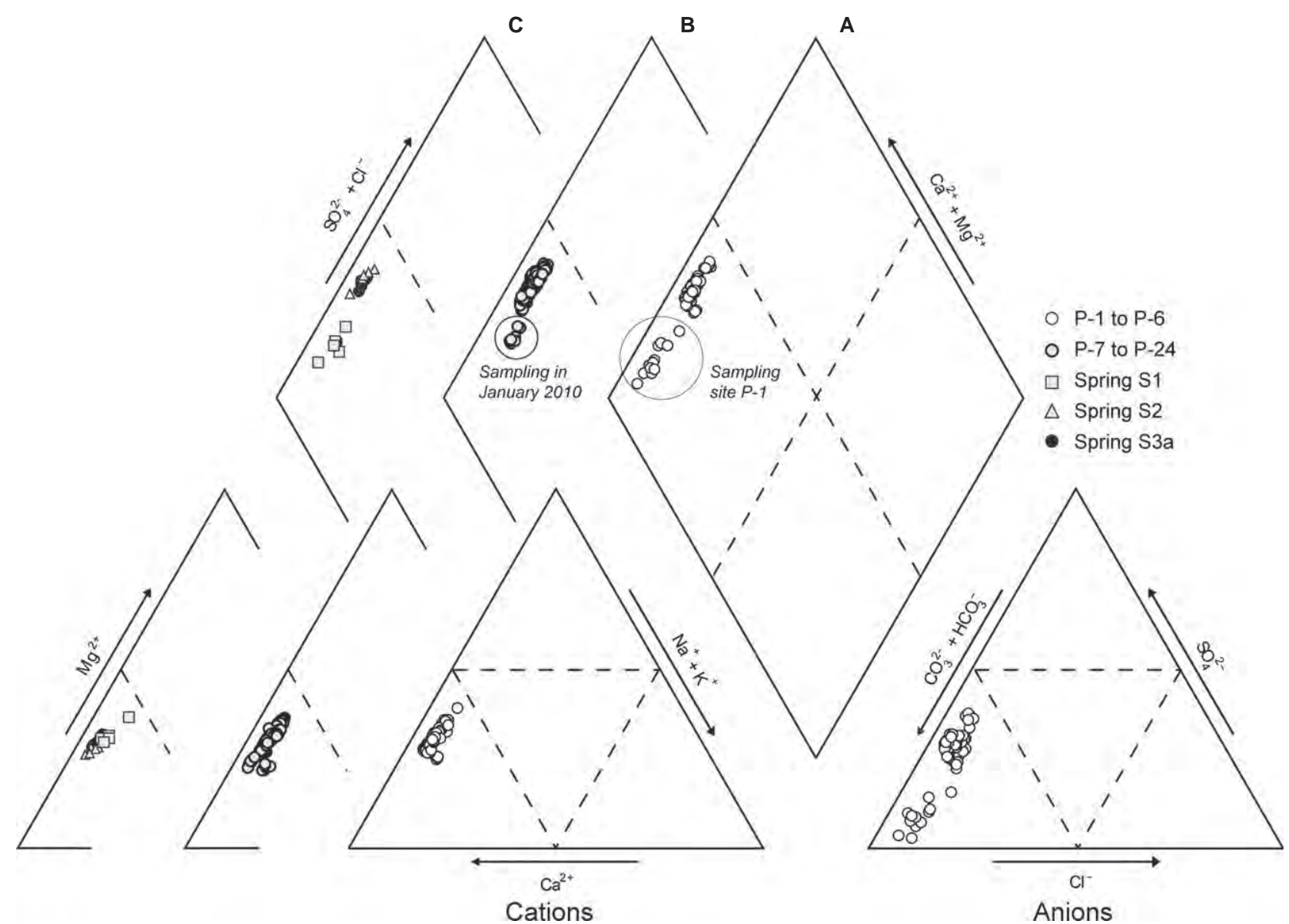

Fig. 9. Piper plot of the studied water samples in the River Piedra (1999 to 2012). (A) River waters from site P-1 to P-6. (B) River waters from site P-7 to P-24. (C) Monitored spring waters: S1, S2 and S3a. Location of sites is shown in Figs 1 and 4.

springs located between P-23 and P-24. Decreasing trends in the $\mathrm{pH}$, PWP and SIc values, as well as increases in the $\log \mathrm{pCO}_{2}$ values (Fig. 10), would support the existence of meaningful ground water contribution between P-23 and P-24 (hereafter referred to as S4 Fig 4), which may affect the tufa precipitation pattern in this part of the river channel (see below).

\section{Temporal trends}

The chemical features of the main spring feeding the River Piedra (S2; Fig. 4), and especially those related to the carbonate system, are remarkably constant through time, with values (mean $\pm 1 \sigma$ ) of $7 \cdot 16 \pm 0 \cdot 16$ for $\mathrm{pH}, 294 \cdot 8 \pm 9 \cdot 9 \mathrm{mg} \mathrm{L} \mathrm{L}^{-1}$ for alkalinity, $105 \cdot 8 \pm 5 \cdot 4 \mathrm{mg} \mathrm{L}^{-1}$ for Ca and $68 \cdot 7 \pm$ $5.04 \mathrm{mg} \mathrm{L}^{-1}$ for TDIC during all of the six-month monitoring periods from June 2009 to June 2012. The available analytical data from the Confederacion Hidrográfica del Ebro for the years 2002 and 2006 also support this view. Thus, no seasonal trends occurred (even temperature is rather constant at this spring, with values of $15.5 \pm 1.5^{\circ} \mathrm{C}$ ) in these ground waters.

This feature appears to influence the temporal evolution of the River Piedra waters because most of the compositional characteristics along the studied stretch do not exhibit systematic seasonal trends. However, the overall conductivity, TDIC, alkalinity and Ca values appear to be slightly higher in the cool than in the warm periods, although a certain degree of overlap can be observed between the periods (see box and whisker plots in Fig. 10). The water temperature (reflecting variations in the air temperature), PWP and, to a lesser extent, SIc values (also dependent on temperature), showed a clearer seasonal fluctuation with higher values in the warm periods (Fig. 10A, D and H).

Between sites P-3 and P-22, the aforementioned decreases in $\mathrm{Ca}$ and alkalinity contents usually show a steeper reduction pattern during the warm periods than during the cool periods 

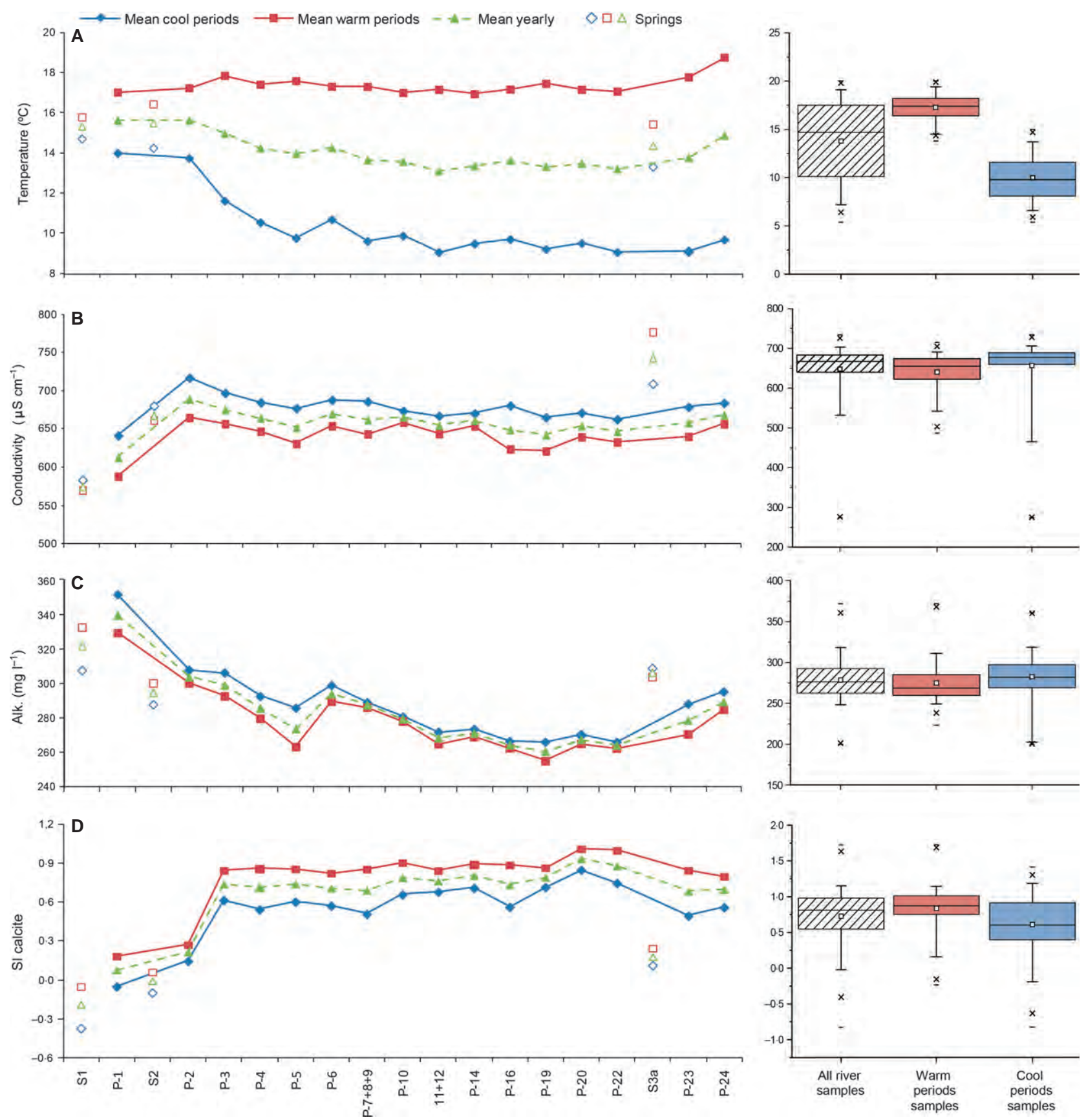

Fig. 10. Evolution of the mean values (yearly and six-monthly; i.e. cool and warm periods) of the main hydrochemical parameters monitored along the river and in springs (note that space is not to scale; see Fig. 4 for location of sites). Box and whisker plots showing the statistical distribution of the main hydrochemical parameters monitored at the river sites. The statistics have been performed for all water samples and for the samples of the warm and cool periods. The statistical measures plotted are the median (horizontal line inside the box), the 25th and 75th percentiles (bottom and top of the box), the mean (square), the 5th and 95th percentiles ('whiskers'), the 1st and 99th percentile (crosses) and the maximum and minimum values (horizontal bars).

(this pattern is obscured at the Natural Park due to the water diverted from and then returned to the main stream by multiple natural and artificial channels; see Vázquez-Urbez et al., 2010). The SIc mean values are clearly higher in the warm $(c a+0.9)$ than in the cold periods ( $c a$
+0.6; Fig. 10D) but, in both cases, they appear to be high enough to overcome the carbonate kinetic precipitation barrier (Jacobson \& Usdowski, 1975; Dandurand et al., 1982; Suarez, 1983; Drysdale et al., 2002; Malusa et al., 2003; Lojen et al., 2004). Furthermore, in other tufa-deposit- 

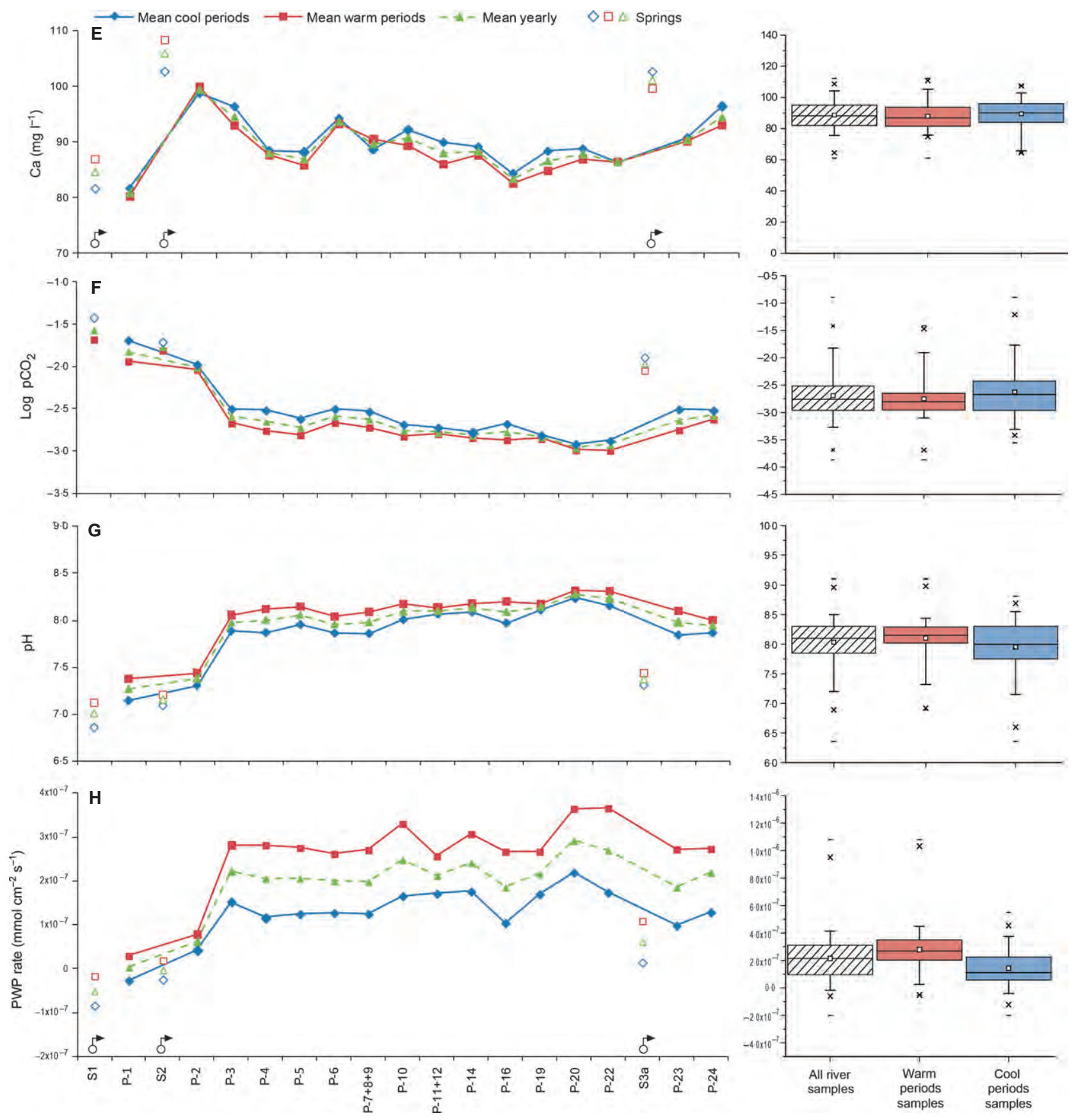

Fig. 10. (Continued).

ing fluvial systems, the PWP seasonal patterns have shown a positive correlation with the seasonal sedimentation rates (Kano et al., 2003; Kawai et al., 2006, 2009).

Thus, all of these hydrochemical characteristics suggest that tufa formation is a continuous process between sites P-3 and P-22 in the River Piedra, but it is greater during the warm periods than in the cool periods. This seasonal trend in tufa formation is also consistent with the slightly higher values in TDIC, alkalinity and Ca observed in the cool periods, when the deposition rate is smaller.

\section{TUFA DEPOSITION RATES}

The deposition rates of the 24 tablets installed along the river had highly variable values, depending on the depositional environmental conditions and their spatial distribution along the 

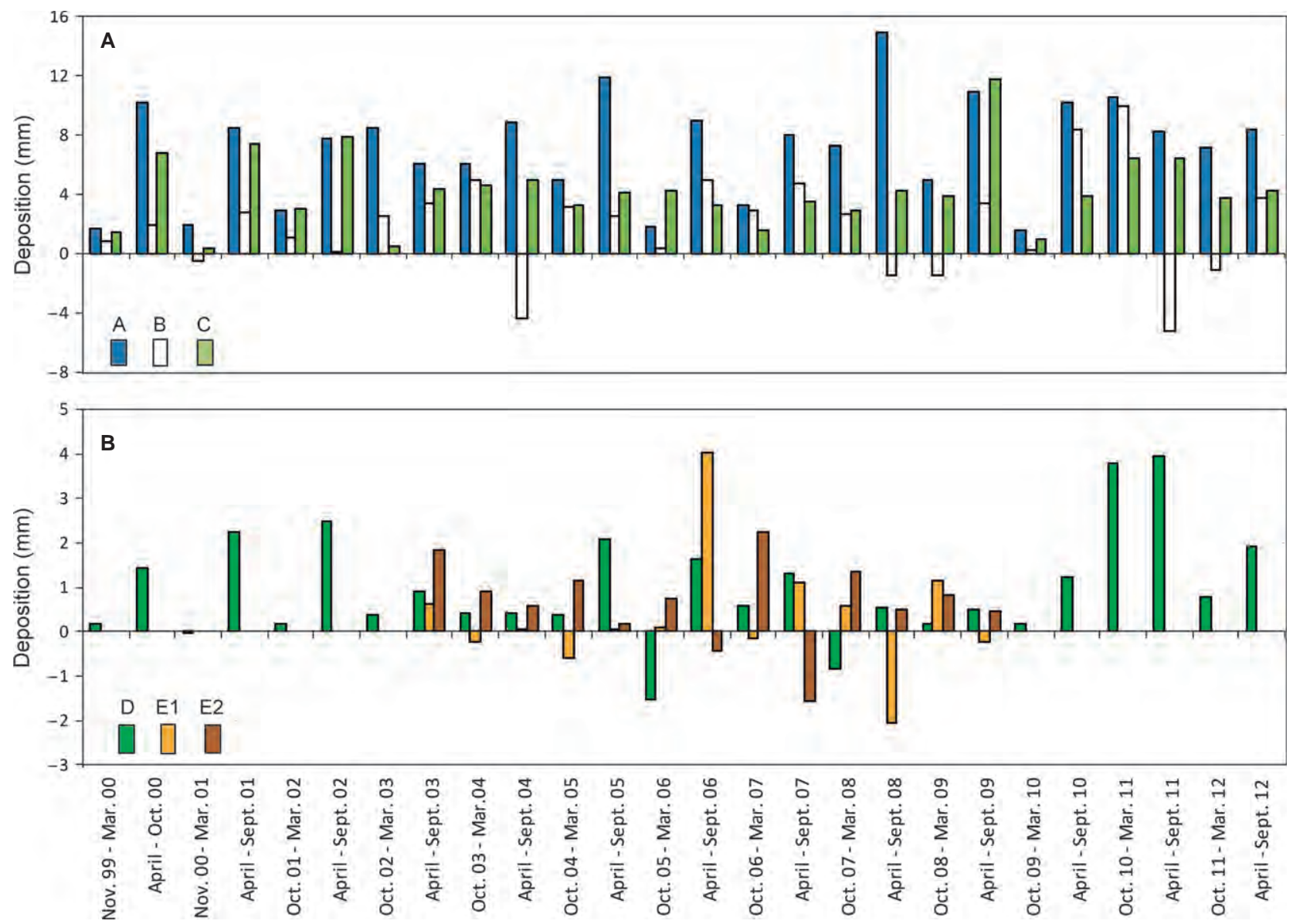

Fig. 11. Mean six-month deposition on tablets distributed by depositional environmental settings through the studied period. (A) Facies A, B and C. (B) Facies D, E1 and E2.

river. Moreover, differences were also observed through time.

\section{Depositional environmental variations}

The mean yearly rates of the 24 monitored sites varied between $0.74 \mathrm{~mm}$ (facies E1) and $16.53 \mathrm{~mm}$ (facies A; Table 2; Fig. 11). The highest rates were measured at sites with fast water flow on tablets with facies A (sites P-5, P-14, P-16, P-17 and P-20; Tables 2 and 3); these ranged between $6.77 \mathrm{~mm} \mathrm{yr}^{-1}$ and $16.53 \mathrm{~mm} \mathrm{yr}^{-1}$ (mean of facies A: $13.75 \mathrm{~mm} \mathrm{yr}^{-1}$ ). The mean six-month deposition of tablets with facies A was always positive. Only two tablets with facies A recorded negative six-month thickness in two cool periods (2005 to 2006 and 2008 to 2009), and very few recorded small positive values (much lower than the mean) in some warm periods (Fig. 11A).

In contrast, the tablets in slow-flowing water areas with facies B1 and B2 (sites P-4, P-6, P-7, $\mathrm{P}-10$ and $\mathrm{P}-22$ ) recorded lower rates, from 1.16 to $5.64 \mathrm{~mm} \mathrm{yr}^{-1}$ (Tables 2 and 3). Some tablets with facies $\mathrm{B}$ recorded negative values during nine six-month periods, both cool and warm, resulting in negative mean deposition rates for six six-month periods (Fig. 11A).

The tablets installed in stepped waterfalls recorded highly variable deposition rates (mostly of facies C), from 0.95 to $13.16 \mathrm{~mm}$ $\mathrm{yr}^{-1}$. Some tablets with facies $\mathrm{C}$ recorded negative and small positive (less than the mean) values during a few six-month periods, but the mean six-month deposition was always positive (Fig. 11A).

The sedimentation in spray areas (facies D) was among the lowest, with rates from 0.83 to $1.93 \mathrm{~mm} \mathrm{yr}^{-1}$ (sites P-13 and P-18) (Tables 2 and 3). Similar low rates were recorded by tablets with facies $\mathrm{E}$ (the mean of facies E1 was $0.88 \mathrm{~mm}$

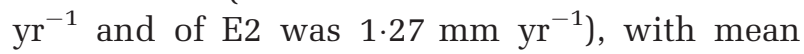
yearly rates $<1 \mathrm{~mm}$ (sites $\mathrm{P}-1, \mathrm{P}-2$ and $\mathrm{P}-24$ ), with the exception of tablet $\mathrm{P}-23$, which recorded $1.80 \mathrm{~mm} \mathrm{yr}^{-1}$. Negative six-month deposition values were measured for some tablets with facies $\mathrm{E}$ over ten six-month periods (Table 2; Fig. 11B). 


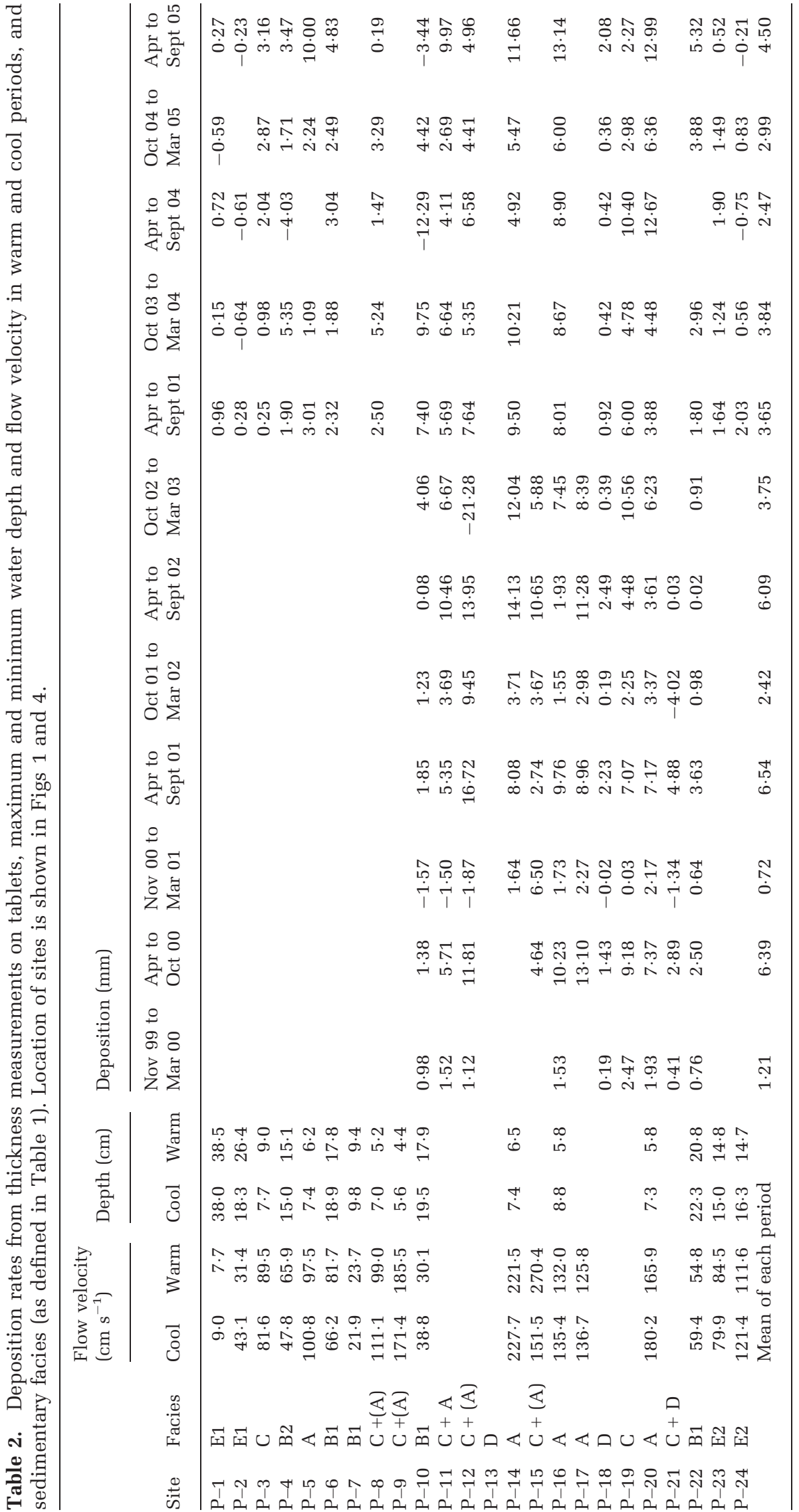




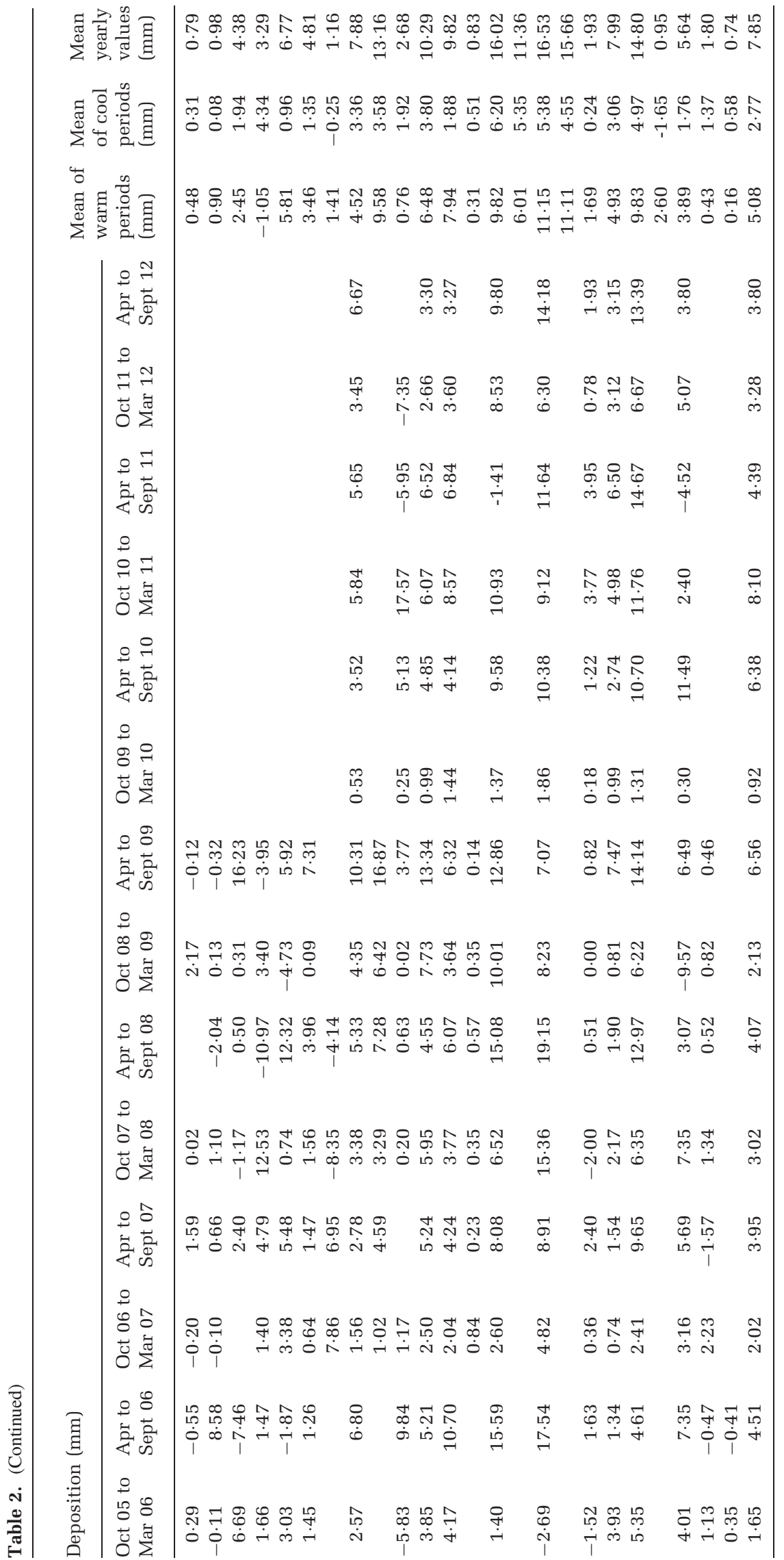


Table 3. Summary of the mean thickness of sediment deposited in the different depositional settings examined along the River Piedra from 1999 to 2012.

\begin{tabular}{|c|c|c|c|c|c|}
\hline $\begin{array}{l}\text { Depositional environmental } \\
\text { settings }\end{array}$ & Facies & Tablet number & $\begin{array}{l}\text { Mean of warm } \\
\text { periods (mm) }\end{array}$ & $\begin{array}{l}\text { Mean of cool } \\
\text { periods (mm) }\end{array}$ & $\begin{array}{l}\text { Mean } \\
\text { yearly }(\mathrm{mm})\end{array}$ \\
\hline Fast-flowing water areas & A & P-5, P-14, P-16, P-17, P-20 & $9 \cdot 34$ & $4 \cdot 41$ & $13 \cdot 75$ \\
\hline $\begin{array}{l}\text { Slow-flowing and standing } \\
\text { water areas }\end{array}$ & $\begin{array}{l}\text { B1 } \\
\text { B2 }\end{array}$ & $\begin{array}{l}\text { P-6, P-7, P-10, P- } 22 \\
\text { P-4 }\end{array}$ & $\begin{array}{r}2 \cdot 38 \\
-1 \cdot 05\end{array}$ & $\begin{array}{l}1 \cdot 19 \\
4 \cdot 34\end{array}$ & $\begin{array}{l}3 \cdot 57 \\
3 \cdot 29\end{array}$ \\
\hline $\begin{array}{l}\text { Stepped waterfalls with } \\
\text { continuous jet }\end{array}$ & $\mathrm{C}$ & $\begin{array}{l}\text { P-3, P-8, P-9, P-11, P-12, } \\
\text { P-15, P-19, P-21 }\end{array}$ & $5 \cdot 57$ & $2 \cdot 68$ & $8 \cdot 25$ \\
\hline Spray areas near waterfalls & $\mathrm{D}$ & P-13, P-18 & $1 \cdot 00$ & $0 \cdot 38$ & $1 \cdot 38$ \\
\hline $\begin{array}{l}\text { Areas with gravel and } \\
\text { cobble sediment }\end{array}$ & $\begin{array}{l}\text { E1 } \\
\text { E2 }\end{array}$ & $\begin{array}{l}\mathrm{P}-1, \mathrm{P}-2 \\
\mathrm{P}-23, \mathrm{P}-24\end{array}$ & $\begin{array}{l}0 \cdot 69 \\
0 \cdot 30\end{array}$ & $\begin{array}{l}0 \cdot 19 \\
0 \cdot 98\end{array}$ & $\begin{array}{l}0 \cdot 88 \\
1 \cdot 27\end{array}$ \\
\hline
\end{tabular}
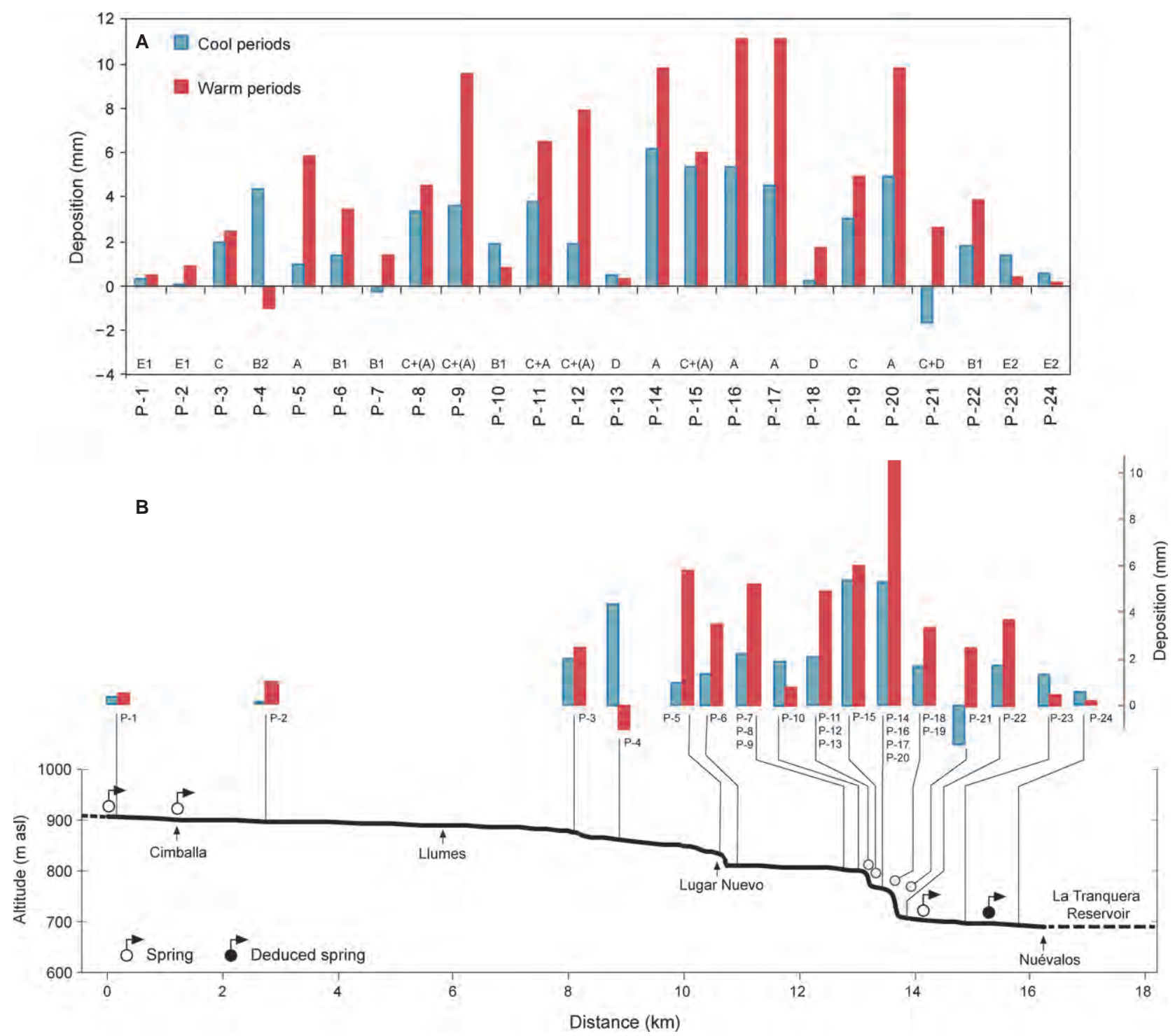

Fig. 12. (A) Distribution of mean six-month deposition values along the river (recorded by all monitored tablets through the studied period), with an indication of the facies at each site. (B) Distribution of mean six-month deposition values along the topographical profile. Note that some columns represent values of several sites.

(C) 2013 The Authors. Journal compilation (C) 2013 International Association of Sedimentologists, Sedimentology, 61, 90-132 

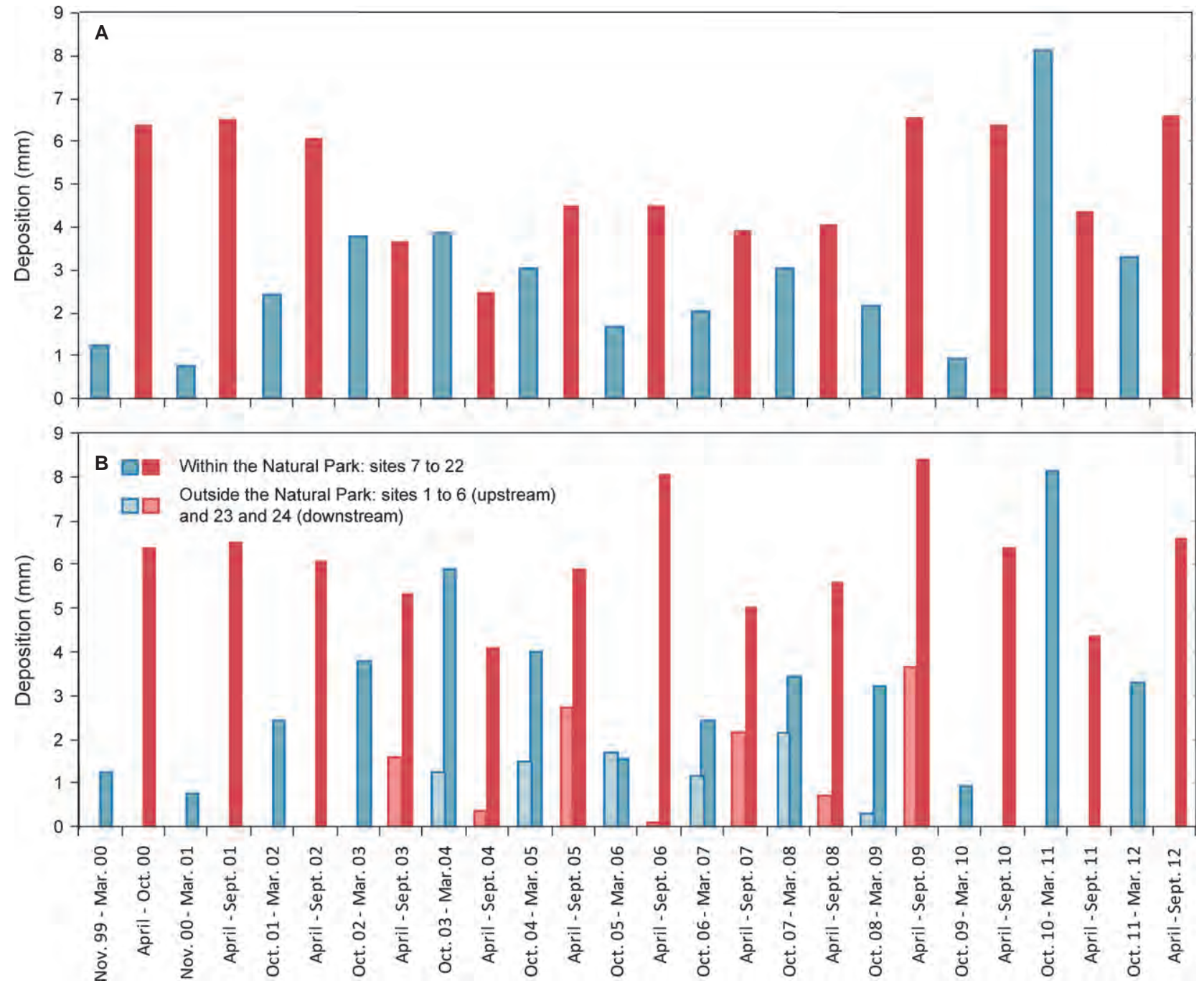

Fig. 13. (A) Mean six-month deposition of all tablets monitored from November 1999 to September 2012. (B) The same as (A), with an indication of values for tablets outside and inside the Natural Park. Tablets outside the Park were monitored from April 2003 to September 2009.

\section{Spatial variations of deposition rates}

The long monitored stretch of the river displayed very low deposition rates $(<2 \mathrm{~mm}$ $\mathrm{yr}^{-1}$ ) in the most upstream and downstream reaches (tablets P-1, P-2 and P-23 and P-24; Tables 2 and 3; Fig. 12). The carbonate sediment was scarce or absent on tablets P-1 and P-2 (facies E1), and tablets P-23 and P-24 (facies E2) had negative deposition values during some sixmonth periods. Higher rates were recorded on many tablets between sites P-3 and P-22, although great differences were observed in accordance with the environmental setting (i.e. facies D formed in spray areas, facies B1 in some slow-flowing water areas and facies $\mathrm{C}$ and $\mathrm{D}$ at site P-21; in all cases $<2 \mathrm{~mm} \mathrm{yr}^{-1}$-Table 2). The highest values (from 10 to $16.5 \mathrm{~mm} \mathrm{yr}^{-1}$ ) corre- sponded to facies A and C within the Natural Park, between sites P-9 and P-20, coinciding with the stretch of steeper slope along the fluvial profile (Table 2; Fig. 12).

\section{Temporal variations of depositional rates}

The mean deposition rates from all the tablets throughout the study interval were higher during the warm periods (total mean: $5.08 \mathrm{~mm}$ ) than during the cool periods (total mean: $2.77 \mathrm{~mm}$; Table 2; Fig. 13). Most tablets (19 out of 24) recorded such six-month variation, with rates in the warm periods being approximately two-fold or even greater with respect to those of the cool periods, irrespective of environmental settings and spatial distribution of the tablets along the river (Table 2; Figs 11, 12 and 13). 
Exceptions to that pattern corresponded to tablets with very small $\left(<2 \mathrm{~mm} \mathrm{yr}^{-1}\right.$; for example, sites P-23 and P-24, with facies E2; site P-13, with facies D) and small (ca 2.68 and $3.29 \mathrm{~mm}$ $\mathrm{yr}^{-1}$; for example, sites P-10 and P-4, with facies B1 and B2, respectively) deposition rates. Except for the mentioned cases with reverse six-month deposition values, the mean deposition rates at sites monitored along the river ranged from 0.48 to $11.15 \mathrm{~mm}$ during the warm periods and from 0.08 to $6.20 \mathrm{~mm}$ during the cool periods (Table 2).

The mean deposition for the 26 monitored six-month periods (considering all tablets) also exhibited a six-month pattern, although large differences were recorded through time (Table 2; Fig. 13). The values for the warm periods ranged from $2.47 \mathrm{~mm}$ (Warm 2004) to $6.61 \mathrm{~mm}$ (Warm 2012) and those for the cool periods ranged from $0.72 \mathrm{~mm}$ (Cool 2000-01) to $3.84 \mathrm{~mm}$ (Cool 2003-04), with the exception of $8.10 \mathrm{~mm}$, which was recorded in Cool 2010-11 (Fig. 13A).

The largest deposition rates of the warm periods ( $>6 \mathrm{~mm} / \mathrm{six}$-month period) were recorded by tablets within the Natural Park (Fig. 13B) which, in general, had the greatest increases with respect to the closer cool periods. There is only one warm period (Warm 2009) in which tablets outside the Park recorded almost $4 \mathrm{~mm}$. In general, the tablets outside of the Park presented less pronounced rate differences between the cool and warm periods (Table 2; Fig. 13B).

The lowest mean rates in some cool and some warm periods (much lower than the mean values of cool and warm periods, i.e. $<1 \mathrm{~mm}$ and $<2.5 \mathrm{~mm}$, respectively) were mostly associated with very small deposition values (either negative or positive, but suggestive of erosion) on some tablets (for example, Cool 2000-01, 2005-06 and 2009-10; Warm 2004). There were also cool periods with higher than normal values (for example, Cool 2002-03, 2003-04 and 2010-11; Table 2; Fig. 13).

\section{RESULTS FROM PRINCIPAL COMPONENTS ANALYSIS}

The principal components analysis (PCA) was performed with a dataset including all of the hydrochemical variables $(10$ analysed variables - temperature, $\mathrm{pH}, \mathrm{Ca}, \mathrm{Mg}, \mathrm{Na}, \mathrm{K}, \mathrm{Cl}$, $\mathrm{SO}_{4}$, alkalinity and conductivity - and four calculated variables - $\mathrm{pCO}_{2}$, SIc, TDIC and PWP), measured water velocity, mean monthly air temperature and discharge values (corresponding to

Table 4. Principal component loadings and explained variance for the five initial components. Loadings (that represent the importance of the variables for the components) $>0 \cdot 6$ are marked in bold type.

\begin{tabular}{|c|c|c|c|c|c|}
\hline & PC1 & PC2 & PC3 & PC4 & PC5 \\
\hline Water temperature & $-0 \cdot 1754$ & $0 \cdot 3294$ & $-0 \cdot 8645$ & $0 \cdot 1122$ & $-0 \cdot 1476$ \\
\hline Conductivity & $0 \cdot 4802$ & $\mathbf{0 \cdot 6 7 9 7}$ & $0 \cdot 2808$ & $0 \cdot 1359$ & $-0 \cdot 0474$ \\
\hline $\mathrm{pH}$ & -0.9409 & $0 \cdot 1778$ & $0 \cdot 1013$ & $-0 \cdot 0796$ & $0 \cdot 1584$ \\
\hline Alkalinity & $\mathbf{0} \cdot 8105$ & $0 \cdot 2537$ & $-0 \cdot 1239$ & $-0 \cdot 1984$ & $0 \cdot 0784$ \\
\hline $\mathrm{Cl}$ & $0 \cdot 1583$ & $0 \cdot 1586$ & -0.4653 & $-0 \cdot 3525$ & $-0 \cdot 2069$ \\
\hline $\mathrm{SO}_{4}$ & $-0 \cdot 1254$ & $0 \cdot 7275$ & $0 \cdot 3832$ & $0 \cdot 2292$ & $0 \cdot 0062$ \\
\hline $\mathrm{Na}$ & $0 \cdot 2183$ & $0 \cdot 0590$ & $-0 \cdot 0744$ & $0 \cdot 6435$ & $0 \cdot 3917$ \\
\hline K & $-0 \cdot 0461$ & $-0 \cdot 2611$ & $-0 \cdot 2124$ & $0 \cdot 5205$ & $0 \cdot 3557$ \\
\hline $\mathrm{Ca}$ & $0 \cdot 2652$ & $0 \cdot 6784$ & $0 \cdot 1265$ & $-0 \cdot 2402$ & $0 \cdot 2488$ \\
\hline $\mathrm{Mg}$ & $0 \cdot 5067$ & $0 \cdot 6739$ & $0 \cdot 0447$ & $0 \cdot 3068$ & -0.0853 \\
\hline TDIC & 0.8804 & $-0 \cdot 0083$ & $-0 \cdot 1673$ & $-0 \cdot 1491$ & $-0 \cdot 0467$ \\
\hline $\mathrm{pCO}_{2}$ & $\mathbf{0 . 9 5 0 1}$ & $-0 \cdot 1287$ & $-0 \cdot 1494$ & $0 \cdot 0692$ & $-0 \cdot 1584$ \\
\hline SI calcite & $-\mathbf{0 . 8 9 1 9}$ & $0 \cdot 3333$ & -0.0351 & $-0 \cdot 1130$ & $0 \cdot 1810$ \\
\hline PWP rate & $-0 \cdot 8062$ & 0.4390 & $-0 \cdot 2199$ & $-0 \cdot 1528$ & $0 \cdot 1380$ \\
\hline Water velocity & $-0 \cdot 4075$ & -0.0714 & $0 \cdot 3669$ & $0 \cdot 1405$ & -0.5599 \\
\hline $\begin{array}{l}\text { Monthly discharge } \\
\text { (sampling month) }\end{array}$ & $-0 \cdot 1957$ & $-0 \cdot 6742$ & -0.2039 & $0 \cdot 1997$ & $-0 \cdot 0543$ \\
\hline $\begin{array}{l}\text { Monthly air temperature } \\
\text { (sampling month) }\end{array}$ & $-0 \cdot 2618$ & $0 \cdot 3914$ & $-0 \cdot 7996$ & $0 \cdot 1706$ & $-0 \cdot 1684$ \\
\hline $\begin{array}{l}\text { Six-monthly } \\
\text { deposition rate }\end{array}$ & $-0 \cdot 3149$ & $0 \cdot 2063$ & $0 \cdot 1197$ & $0 \cdot 3293$ & $-0 \cdot 6412$ \\
\hline Variance (\%) & $31 \cdot 76$ & $17 \cdot 68$ & $12 \cdot 39$ & $7 \cdot 49$ & $7 \cdot 11$ \\
\hline Cumulative (\%) & $31 \cdot 76$ & $49 \cdot 44$ & $61 \cdot 83$ & $69 \cdot 32$ & $76 \cdot 43$ \\
\hline
\end{tabular}

(C) 2013 The Authors. Journal compilation (C) 2013 International Association of Sedimentologists, Sedimentology, 61, 90-132 
the sampling month) and six-month rates of tufa sedimentation in the tablets. Then, five principal components (out of 18) were retained, and those explained $76.43 \%$ of the variance contained in the original data set (Table 4). The data from the springs were not included.

Component 1 (PC1) explains the greatest amount of the variance, showing highly positive loadings in alkalinity, partial pressure of $\mathrm{CO}_{2}$ and TDIC values (and highly negative values for the $\mathrm{pH}$, SIc and PWP). Thus, this component represents a 'carbonate component' directly related to the main processes $\left(\mathrm{CO}_{2}\right.$ outgassing, calcite precipitation and ground water inputs) affecting the hydrochemical evolution of dissolved carbon and related parameters.

Component 2 (PC2) indicates high positive loadings in conductivity and in the other main dissolved ions $\left(\mathrm{SO}_{4}, \mathrm{Ca}\right.$ and $\left.\mathrm{Mg}\right)$, whereas it indicates high negative loadings in mean monthly discharge values. Thus, it may represent a 'salinity component' affected not only by the discharge (for example, dilution effects) but also by the tufa sedimentation (through dissolved Ca contents).

Component 3 (PC3) represents a 'temperature component' totally dominated by water temperature and mean monthly air temperature. Each of the last two components (PC4 and PC5) explains approximately $7 \cdot 0 \%$ of the variance, indicating that these are related to more local effects than the first three components.

As shown in Fig. 14A, there is a substantial overlap between the scores from the warm and the cool periods. Site P-1, which was affected by the distinctive hydrochemical characteristics of spring S1, defines an extreme group mainly due to the effect of the high $\mathrm{pCO}_{2}$ values (or low $\mathrm{pH}$ values) in the fourth quadrant. Furthermore, the data from the January 2010 sampling define a separate group in the third quadrant that was mainly affected by discharge (with the opposite effects for conductivity).

In Fig. 14B, the inclusion of the 'temperature component' (PC3) clearly separates the warm and the cool sampling periods (except for January 2010), and the effects of the 'carbonate component' (PC1) on the scores of both groups can be observed. From the scores corresponding to sites $\mathrm{P}-1$ and $\mathrm{P}-2$ (in the fourth quadrant, mainly contributed by $\mathrm{pCO}_{2}$ and alkalinity loadings due to the large ground water inputs at these sites), both groups define roughly parallel trends with decreasing PC1 values for the rest of the sites. Both trends can be interpreted as a result of the $\mathrm{CO}_{2}$ outgassing and tufa sedimentation processes in this stretch, promoting decreases in TDIC, alkalinity and $\mathrm{pCO}_{2}$ values and increases in SIc and PWP values (thus, decreasing the PC1 values through the loadings of these variables; Table 4). However, the samples from warm periods show a higher contribution of PWP and SIc loadings (apart from that of temperature) and a slightly lower contribution of dissolved Ca than samples from cool periods, suggesting the existence of an overall higher precipitation rate in the warm periods.

Overall, the six-month deposition rates recorded by the tablets do not demonstrate significant loadings in the extracted components. This may be because these values represent six-month periods, whereas most of the other variables (for example, chemical analysis) correspond to discrete values measured at a particular moment within these six-month periods. However, from the projection of the original variables in the PC space (Fig. 14), the sixmonth rates appear to show some relation with temperature and PWP (Fig. 14A) and with velocity values (Fig. 14B). These relations are discussed further in the next section.

\section{DISCUSSION}

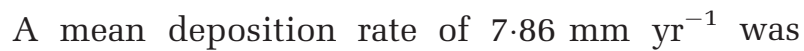
measured from a total of 24 tablets set throughout the River Piedra from November 1999 to September 2012; this value is very similar to that obtained from 14 tablets within the area of the Natural Park for the first five years $(7.52 \mathrm{~mm}$ $\mathrm{yr}^{-1}$; Vázquez-Urbez et al., 2010), although the latter study included the cave environment which had negligible deposition. The deposition rates obtained from the different methods and experimental conditions range between $1 \mathrm{~mm}$ $\mathrm{yr}^{-1}$ and $10 \mathrm{~mm} \mathrm{yr}^{-1}$ (Emeis et al., 1987; Liu et al., 1995; Drysdale \& Gillieson, 1997; MerzPreiß \& Riding, 1999; Yoshimura et al., 2004; Gradziński, 2010) and were recorded during one to two-year monitoring intervals in different climate and hydrology conditions. This study provides a longer time series of data all the way along the river, which allows for the discussion of variations of some sedimentological and hydrochemical characteristics of the fluvial tufa system through space and time, as well as for the determination of their relations with climate and hydrology. 

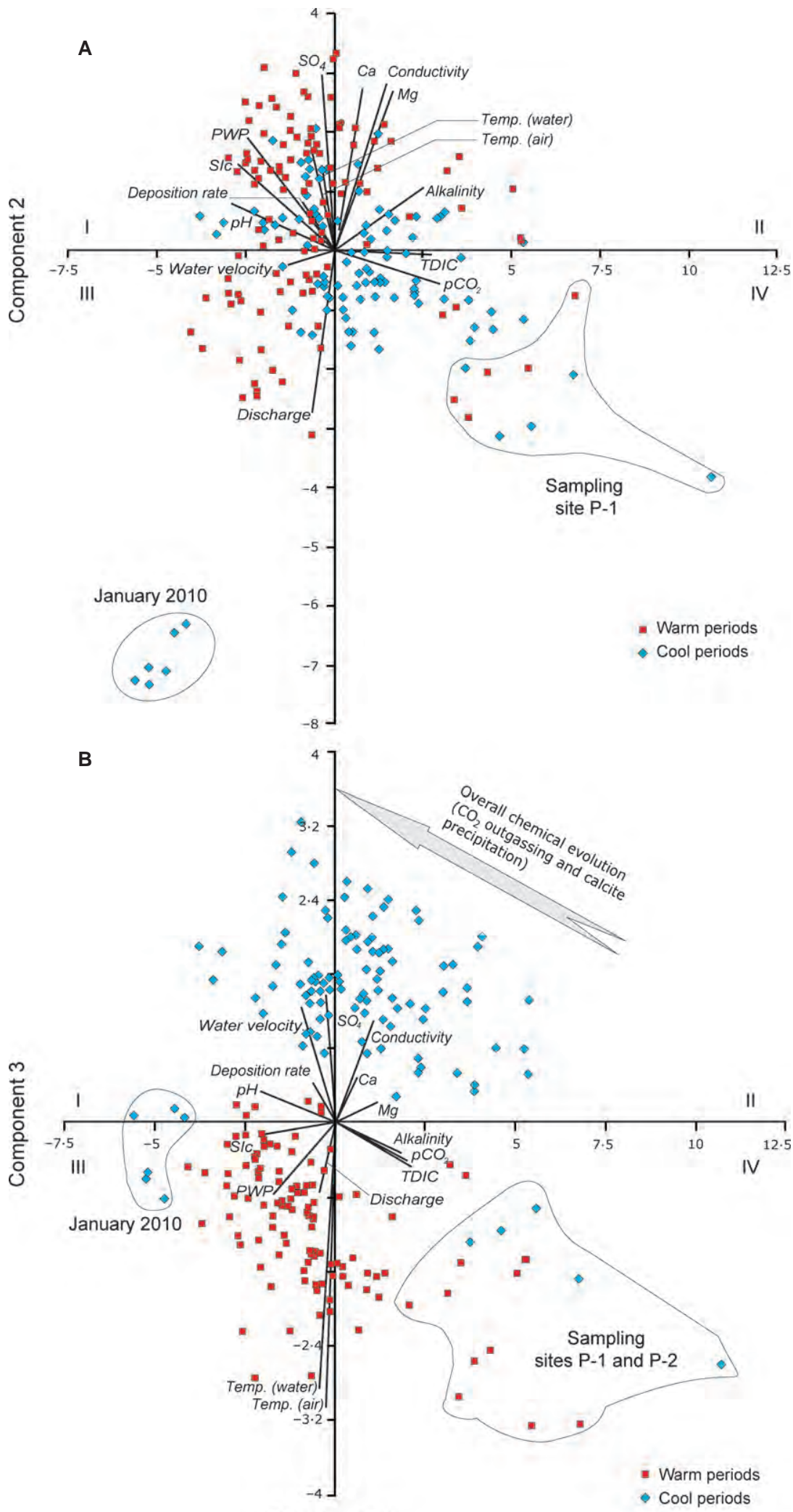

Component 1

Fig. 14. Bivariate plots of the scores of PCs 1 and 2 (A) and PCs 1 and 3 (B) for all the sampling sites and monitored periods in the River Piedra (spring data are excluded). Discharge and air temperature correspond to mean monthly values of the sampling month. Deposition rates correspond to six-month values measured on tablets (Table 2). 


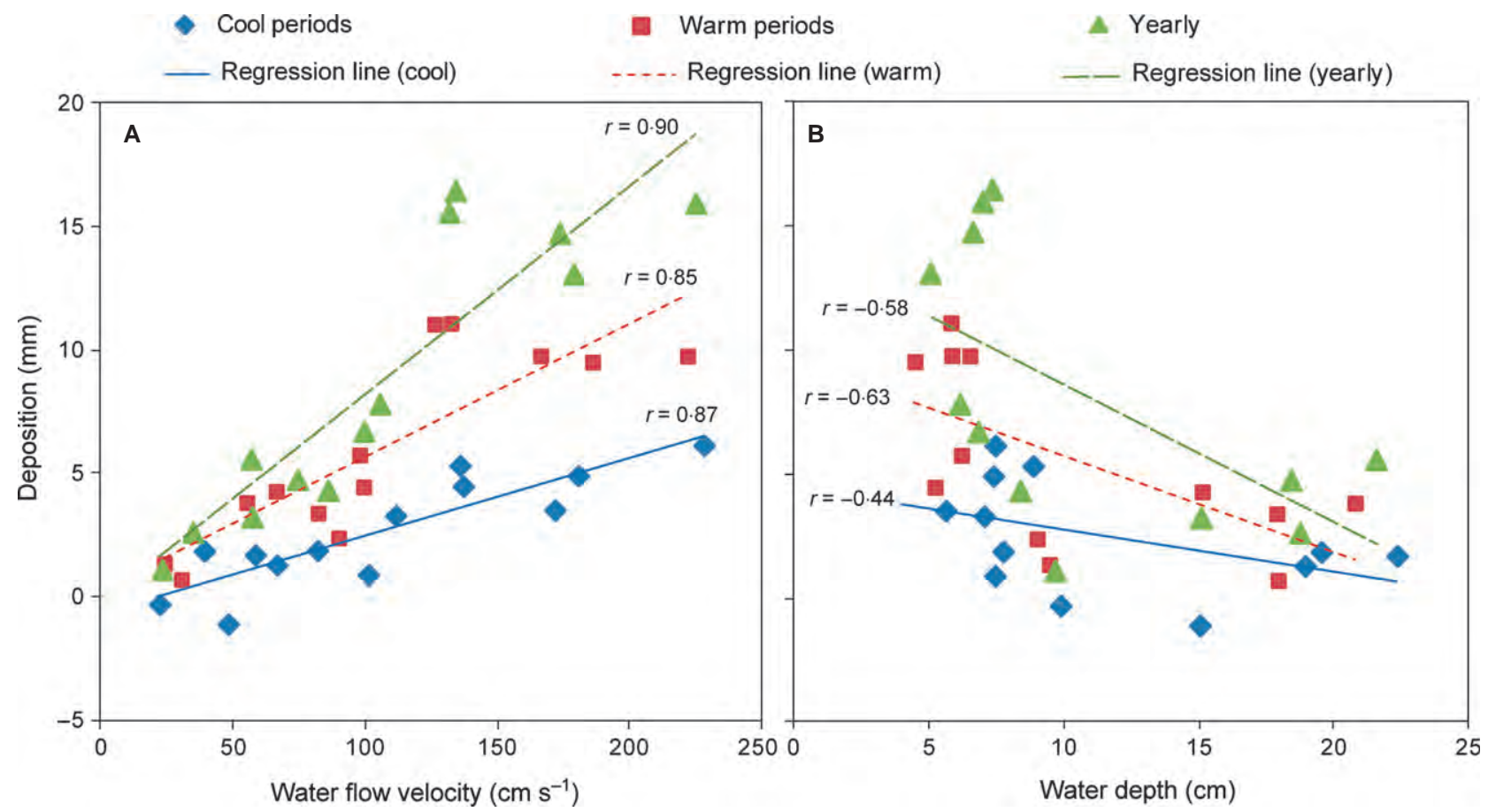

Fig. 15. Correlation between yearly and six-month deposition rates and water flow velocity (A) and between yearly and six-month deposition rates and water depth (B).

\section{Deposition rates and intrinsic factors}

The highest mean yearly deposition rates were recorded by tablets installed in fast-flowing water areas (facies A) and stepped waterfalls (facies C), while lower rates were obtained in slow-flowing (facies B) and spray (facies D) areas. A clear relation was obtained between the yearly deposition rates and water velocity $(r=0.90)$ for sites with fast-flowing and slowflowing water and some stepped waterfalls (Fig. 15A). As discussed by many authors (e.g. Drysdale \& Gillieson, 1997; Chen et al., 2004), high flow velocities and turbulence enhance $\mathrm{CO}_{2}$ loss from water, which favours calcite precipitation. In addition, $\mathrm{CO}_{2}$ loss is favoured by aeration and jet-flow effects in waterfalls and jumps (Zhang et al., 2001). Moreover, the thickness of the diffusion boundary layers between the solidwater and water-air interfaces diminishes with fast and turbulent conditions, thus facilitating the diffusion through them (Dreybrodt, 1981; Dreybrodt \& Buhmann, 1991; Liu et al., 1995; Chen et al., 2004; Kano et al., 2007). Therefore, the small jumps, rapids and stepped waterfalls, with shallow and turbulent flow, are loci of faster tufa sedimentation. Accordingly, less calcite precipitation is produced in standing and slowflowing water areas, with lower mechanical $\mathrm{CO}_{2}$ loss, which is consistent with the smaller depo- sition rates. In such areas, the deposits may also include varying amounts of carbonate grains (allochems, as in facies B1) which are more susceptible to erosion than other facies. In the case of spray areas, the deposition rates were low because of the reduced amount of running water received. Although evaporation may lead to supersaturation in spray areas, the amount of tufa precipitation is small (Zhang et al., 2001). These results agree with the conclusions of other work in relation to present tufa sedimentation (Liu et al., 1995; Drysdale \& Gillieson, 1997; Chen et al., 2004; Kano et al., 2007; Gradziński, 2010; Pedley \& Rogerson, 2010) and confirm those from a preliminary study of the River Piedra (Vázquez-Urbez et al., 2010).

However, the correlation between yearly deposition rates and water velocity (Fig. 15A) has a slightly higher dispersion of data when the water velocity $>1.2 \mathrm{~m} \mathrm{~s}^{-1}$ (Standard deviation $= \pm 38.28$ versus 29.54 ), suggesting that over that value: (i) variations in water velocity did not cause parallel variations in $\mathrm{CO}_{2}$ loss from water; and/or (ii) the deposition rate was also influenced by other parameters, the effects of which are more noticeable above such high flow conditions.

At some sites, very low deposition rates were measured in both very slow-flowing to standing 
Table 5. Correlation coefficient values between the deposition rates from tablets and the main related parameters, sun spots (RI) and NAO index.

\begin{tabular}{|c|c|c|c|c|c|c|}
\hline \multirow[b]{2}{*}{ Monitored sites: } & \multicolumn{2}{|c|}{ All along the river } & \multicolumn{2}{|c|}{ In the Natural Park } & \multicolumn{2}{|l|}{ Facies A } \\
\hline & $\begin{array}{l}\text { Deposition } \\
\text { rate (all } \\
\text { measured } \\
\text { values) }\end{array}$ & $\begin{array}{l}\text { Deposition } \\
\text { rate } \\
\text { (excluding } \\
\text { negative } \\
\text { values) }\end{array}$ & $\begin{array}{l}\text { Deposition } \\
\text { rate (all } \\
\text { measured } \\
\text { values) }\end{array}$ & $\begin{array}{l}\text { Deposition } \\
\text { rate } \\
\text { (excluding } \\
\text { negative } \\
\text { values) }\end{array}$ & $\begin{array}{l}\text { Deposition } \\
\text { rate (all } \\
\text { measured } \\
\text { values) }\end{array}$ & $\begin{array}{l}\text { Deposition } \\
\text { rate } \\
\text { (excluding) } \\
\text { negative } \\
\text { values) }\end{array}$ \\
\hline \multicolumn{7}{|c|}{ Six-monthly periods (warm and cool) $(n=26)$} \\
\hline Discharge & $-0 \cdot 21$ & $-0 \cdot 11$ & -0.07 & $0 \cdot 00$ & $0 \cdot 07$ & $0 \cdot 11$ \\
\hline Precipitation & -0.05 & $0 \cdot 04$ & $0 \cdot 07$ & $0 \cdot 14$ & $0 \cdot 26$ & $0 \cdot 26$ \\
\hline Air temp. & 0.57 & 0.63 & $\mathbf{0 . 6 6}$ & 0.65 & 0.65 & $\mathbf{0 . 6 6}$ \\
\hline Water temp.* & $0 \cdot 46$ & 0.54 & 0.54 & $0 \cdot 55$ & 0.54 & $0 \cdot 58$ \\
\hline Total insolation & $\mathbf{0 . 5 8}$ & 0.64 & $\mathbf{0 . 6 7}$ & $\mathbf{0 . 6 7}$ & $\mathbf{0 . 6 9}$ & $\mathbf{0 \cdot 7 0}$ \\
\hline RI observed & $0 \cdot 08$ & -0.04 & $-0 \cdot 10$ & $-0 \cdot 14$ & $-0 \cdot 20$ & $-0 \cdot 27$ \\
\hline RI smoothed & 0.03 & -0.07 & $-0 \cdot 16$ & $-0 \cdot 17$ & -0.23 & $-0 \cdot 30$ \\
\hline NAO index & $-0 \cdot 12$ & -0.05 & $-0 \cdot 11$ & -0.03 & $-0 \cdot 16$ & -0.08 \\
\hline \multicolumn{7}{|c|}{ Warm periods $(n=13)$} \\
\hline Discharge & -0.60 & $-0 \cdot 27$ & -0.44 & $-0 \cdot 10$ & 0.09 & $0 \cdot 04$ \\
\hline Precipitation & -0.59 & -0.54 & -0.57 & -0.50 & $0 \cdot 18$ & $0 \cdot 07$ \\
\hline Air temp. & $0 \cdot 12$ & $0 \cdot 40$ & 0.38 & 0.59 & -0.31 & 0.06 \\
\hline Water temp..$^{\dagger}$ & -0.30 & -0.24 & $-0 \cdot 34$ & -0.20 & -0.72 & -0.51 \\
\hline Total insolation & -0.20 & 0.37 & 0.17 & 0.67 & 0.09 & 0.38 \\
\hline RI observed & 0.39 & -0.02 & -0.07 & $-0 \cdot 24$ & -0.41 & -0.45 \\
\hline RI smoothed & $0 \cdot 39$ & -0.02 & $-0 \cdot 09$ & $-0 \cdot 23$ & -0.44 & -0.45 \\
\hline NAO index & $-0 \cdot 14$ & $0 \cdot 20$ & $-0 \cdot 10$ & 0.29 & -0.35 & $-0 \cdot 13$ \\
\hline \multicolumn{7}{|c|}{ Cool periods $(n=13)$} \\
\hline Discharge & $0 \cdot 05$ & -0.08 & $0 \cdot 17$ & $0 \cdot 03$ & 0.06 & $0 \cdot 26$ \\
\hline Precipitation & $-0 \cdot 10$ & 0.02 & $0 \cdot 01$ & $0 \cdot 12$ & -0.07 & 0.03 \\
\hline Air temp. & -0.25 & $-0 \cdot 18$ & $-0 \cdot 33$ & $-0 \cdot 30$ & -0.17 & -0.32 \\
\hline Water temp.* & 0.49 & $0 \cdot 37$ & 0.52 & 0.34 & $0 \cdot 20$ & $0 \cdot 34$ \\
\hline Total insolation & $0 \cdot 15$ & $0 \cdot 15$ & $0 \cdot 07$ & $0 \cdot 10$ & $0 \cdot 24$ & 0.20 \\
\hline RI observed & $-0 \cdot 17$ & $-0 \cdot 12$ & -0.24 & -0.22 & -0.21 & -0.34 \\
\hline RI smoothed & -0.17 & -0.09 & $-0 \cdot 23$ & $-0 \cdot 20$ & -0.21 & -0.32 \\
\hline NAO index & 0.09 & $0 \cdot 11$ & $0 \cdot 13$ & $0 \cdot 14$ & $0 \cdot 17$ & $0 \cdot 26$ \\
\hline NAO winter & -0.01 & $0 \cdot 00$ & 0.03 & 0.02 & 0.09 & 0.05 \\
\hline
\end{tabular}

${ }^{*} n=11 ; \dagger n=6$; $\pitchfork n=5$. Note that the correlation increases for sites monitored within the Natural Park and also for facies A. Insolation data $\left(\mathrm{h} \mathrm{day}^{-1}\right.$ ) from Agencia Estatal de Meteorología (Spain). Sunspot Numbers are issued by the NOAA Space Weather Prediction Center (SWPC) in Boulder, Colorado (USA). The official International Sunspot Number (RI) is issued by the Sunspot Index Data Center (SIDC) in Brussels (Belgium), available at http:// sidc.oma.be. NAO index values from Hurrell (1995), available (October 1999 to September 2011) at http://climatedataguide.ucar.edu/guidance/hurrell-north-atlantic-oscillation-nao-index-station-based. Values of $r \geq+0 \cdot 5$ and $r=<-0.5$ are in boldface.

(i.e. site P-1, facies E1) and fast-flowing (i.e. site P-24, facies E2) water areas (Table 2; Figs 11 and 12), which suggests the influence of parameters other than water velocity. The uppermost stretch (sites P-1 and P-2) had invariably low SIc values $(<+0 \cdot 5)$, which justifies the almost absent carbonate precipitation in that stretch (Fig. 10). Similar conclusions were obtained from the nearby River Añamaza (Vázquez-Urbez et al., 2011) and other carbonate fluvial systems (Drysdale et al., 2002; Arp et al., 2010). The lowermost stretch of the River Piedra (sites P-23 and P-24) had variable SIc values, both lower and higher than +0.6 (Fig. 10), thus allowing carbonate precipitation during some periods. However, the erosion during some warm periods at sites P-23 and P-24 caused the deposition rates to be very small or even negative.

The influence of photosynthetic activity on calcite precipitation has been discussed widely. Micro-organisms are considered to play rather passive roles, such as providing nucleation sites 

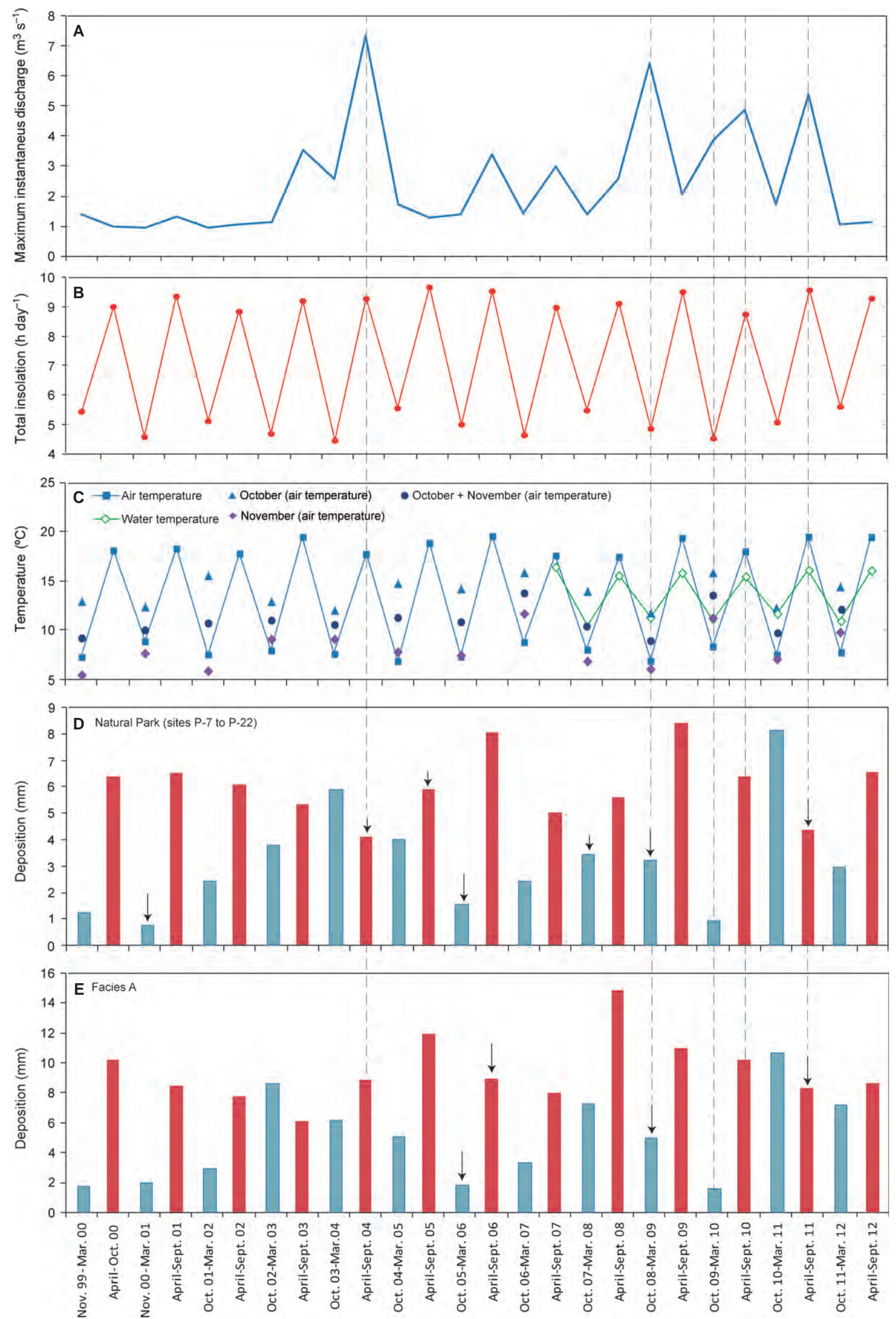

(C) 2013 The Authors. Journal compilation (c) 2013 International Association of Sedimentologists, Sedimentology, 61, 90-132 
for calcite and particle trapping. Usually, the photosynthetic effect is considered important only in low- $\mathrm{CO}_{2}$ and/or slow-flowing contexts, such as standing pools and lakes (Merz-Preiß \& Riding, 1999; Pedley, 2000; Arp et al., 2001; Zhang et al., 2001; Chen et al., 2004). Thus, the amount of $\mathrm{CO}_{2}$ uptake through photosynthesis is generally accepted to be much less than that of physical $\mathrm{CO}_{2}$ outgassing (Lorah \& Herman, 1988; Ford, 1989; Merz-Preiß \& Riding, 1999; Drysdale et al., 2002; Chen et al., 2004). Nevertheless, micro-electrodes and mass balance calculations have proved that cyanobacterial photosynthesis can be of some significance in certain tufa contexts, accounting for as much as 10 to $20 \%$ of the precipitated calcite (Shiraishi et al., 2008, 2010). The method used in this study does not allow for an estimate of the contribution of $\mathrm{CO}_{2}$ uptake through photosynthesis to the depositional rates. Other experimental studies have demonstrated the significant role of the EPS produced by prokaryotes on calcite nucleation in tufas (Pedley et al., 2009; Arp et al., 2010).

Deposition rates may be influenced by the different growth rates and the different types of flora present in different environmental conditions. In fact, distinct facies with different types of flora yielded variable deposition rates, which might indicate that flow conditions somehow controlled the development and type of flora and bacteria and the calcification pattern (MerzPreiß \& Riding, 1999; Pedley \& Rogerson, 2010; Vázquez-Urbez et al., 2010).

The negative correlation between the deposition rates and depth $(r=-0.58$; Fig. 15B) is associated with the predicted inverse relation between the water velocity and depth for more or less constant channel sections. Thus, the tablets with more than $15 \mathrm{~cm}$ of water always recorded rates lower than $6 \mathrm{~mm} \mathrm{yr}^{-1}$, which is consistent with the lower water velocity (thus with less $\mathrm{CO}_{2}$ degassing) in deeper conditions (see Table 1). However, the correlation is far from perfect and although the highest deposition rates (as much as $16.5 \mathrm{~mm} \mathrm{yr}^{-1}$ ) were reached in sites with 4 to $10 \mathrm{~cm}$ of depth, other sites within that depth range recorded much less sediment accumulation. This might be related to the fact that some facies in shallow subenvironments are more susceptible to erosion (for example, facies $\mathrm{C}$ compared with facies A).

This study demonstrates that deposits with facies A (stromatolites; Fig. 6A) were the least affected by erosional processes, whereas those with facies $C$ (porous deposits with mosses and algae; Fig. 8A) were variably affected by erosion depending on the site (i.e. occurring locally and at random). In contrast, facies B (loose sediment and soft laminated deposits; Fig. 7A) and facies E (thin deposits of algae and microbial films; Fig. 5L and $\mathrm{M}$ ) were more susceptible to erosion. Thus, the stromatolite facies are more likely to preserve complete information in the sedimentary record than the other facies (Fig. 11; Table 2).

\section{Variations through space}

The deposition rates from the tablets were much lower at the most upstream and downstream monitored sites (P-1, P-2, P-23 and P-24) and increased between sites P-3 and P-22 (Fig. 12). These variations mostly coincide with changes in slope along the river course (Figs 4 and 10). The highest deposition rates were obtained along the steeper stretch of the river (i.e. within the Natural Park, mostly from sites P-8 to P-20), despite varying rates recorded by distinct environmental settings (Fig. 12A and B). This increase in fluvial slope is associated with the presence of rapids, small jumps and waterfalls (both vertical and stepped) where $\mathrm{CO}_{2}$ outgassing is enhanced and favours thicker (faster) tufa deposition (Zhang et al., 2001; Pentecost, 2005). This agrees with the general decrease in alkalinity, $\mathrm{Ca}$, conductivity and $\mathrm{pCO}_{2}$, as well as with the higher SIc and PWP rate in that part of the river (from P-3 to P-22; Fig. 10). Thus, the precipitation process was triggered and enhanced

\footnotetext{
Fig. 16. Variation of six-month deposition rates and climate and discharge parameters through the studied period. (A) Maximum instantaneous discharge (six-month means from data in Fig. 2). (B) Six-month total insolation. Data from the meteorogical stations of Daroca and Calamocha, provided by the Agencia Estatal de Meteorología (Spain). (C) Six-month air temperature with an indication of some mean monthly values. Data provided by the Agencia Estatal de Meteorología (Spain). Mean water temperature was obtained from continuous recording at sites P-8 and P-22 in this study. (D) Six-month deposition rates from all tablets within the Natural Park. (E) Six-month deposition rates from tablets with facies A. Arrows over columns indicate that 50\% (long arrows) and 25\% (short arrows) of tablets yielded negative deposition values.
} 
by the increase in slope from site P-3 (Figs 4 and 10).

Sites with the least deposition are located within the gently sloped uppermost and lowermost stretches, with low SIc values influenced by the water inputs from springs $\mathrm{S} 1, \mathrm{~S} 2, \mathrm{~S} 3$ and $\mathrm{S} 4$, which had generally high $\mathrm{pCO}_{2}$, particularly in S1 (Fig. 10; Appendix 1). Site P-1 is set apart in Fig. $14 \mathrm{~A}$ by the high $\mathrm{pCO}_{2}$ values. In general, the high $\mathrm{pCO}_{2}$ made those sites ( $\mathrm{P}-1, \mathrm{P}-2, \mathrm{P}-23$ and $\mathrm{P}-24)$ the least favourable to calcite precipitation, although the local water velocity could be moderate to high in some of them. This implies that a long distance from spring inputs would be required to produce enough $\mathrm{CO}_{2}$ loss to raise the SIc and cause calcite precipitation in a generalized fashion. This agrees with the higher SIc observed at site P-3 (some $7 \mathrm{~km}$ downstream of spring S2), from which the SIc increases through site P-22, especially within the Natural Park and in the stretch of higher slope which recorded the highest deposition rates (Figs 10D and 12B).

Most of the river water is provided by springs $\mathrm{S} 1$ and S2, with a mean discharge of $1.4 \mathrm{~m}^{3} \mathrm{~s}^{-1}$ (Fig. 4). In contrast, the downstream springs (S3 and S4) supply a much smaller amount of water (S3 $\approx 0.81 \mathrm{E}-03 \mathrm{~m}^{3} \mathrm{~s}^{-1}$; unknown for $\mathrm{S} 4$ ) that, in turn, is mixed with river water that has been subject to physical, chemical and biological processes through its flowing path. Spring S3a had higher conductivity and slightly lower $\mathrm{pCO}_{2}$ (SIc $<+0 \cdot 2)$ than the springs upstream (S1 and S2). Together, this implies that the effects of such downstream ground water inputs were less noticeable, probably because of their mixing with a much larger volume of river water, but were enough to induce a relative change within the general downstream evolution of the hydrochemical characteristics and a sharp decrease in tufa deposition (Figs 10 and 4B). Ultimately, the changes in slope along the river course, together with the proximity to (or distance from) water spring inputs and their discharge (proportion of ground water with respect to that of the river) conditioned the amount of $\mathrm{CO}_{2}$ dissolved in water at each monitored site in relation to which carbonate deposition rates varied throughout the River Piedra.

\section{Deposition rates and extrinsic factors: variations through time}

The six-month deposition rate pattern (higher values in the warm than in the cool periods) was persistent throughout the 13-year monitor- ing period for most of the studied sites and depositional environmental conditions (i.e. independent of environmental conditions and spatial distribution along the river). However, that pattern was altered in a few cases.

Water velocity, one of the factors with most influence on tufa deposition, did not change significantly between the warm and cool periods, except for a few sites (Table 2), and the river discharge did not correlate with six-month deposition rates $(r=-0 \cdot 21$; Table 5$)$, except for some cases in which high discharge episodes (for example, very high instant discharge related to heavy rain storms; Fig. 3B) caused erosion that lowered the six-month deposition rates. In fact, the correlation between the six-month deposition rates and water velocity was similar for warm and cool periods $(0 \cdot 85$ for warm periods and 0.87 for cool periods; Fig. 15A), suggesting that the differences in deposition rates between the cool and warm periods were mostly influenced by temperature-dependent and other seasonal parameters (for example, day duration, insolation and precipitation). This is clearly shown by the principal components analysis, which distinguishes the two types of periods (warm and cool) based on temperature (PC3; Fig. 14B and Table 4) and highlights the rather local influence of other factors, such as discharge (Fig. 14A).

The correlation between the deposition rates for the cool and warm periods and the mean air temperature for each period is $r=0.57$ (all values included); it increases if only tablets within the park are considered $(r=0.66)$ and if only facies A are considered $(r=0.65$; Fig. 16; Table 5). Similar significant relations are obtained between the deposition rates and insolation for the three groups of data $(r=0.58$, $r=0.67$ and $r=0.69$ ). In all cases, the correlation coefficient increases very slightly when the negative deposition rate values are removed from each period, reaching a maximum of $r=0.70$ in the case of insolation. If the cool period 2010 to 2011 (with an abnormal, high deposition rate; Fig. 13) is excluded, the correlation between the rates and air temperature increases significantly $(r=0 \cdot 75)$. The available continuous record of water temperature (from July 2007) presented no significant correlation with the six-month deposition rates, ranging from 0.46 to $0.58(n=11)$.

The variation in some of the chemical characteristics of the river water (Fig. 10) between the warm and cool periods indicates that the seasonal changes in temperature exert a crucial 
effect on inorganic calcite precipitation through changes in calcite and $\mathrm{CO}_{2}$ solubility in water (Plummer et al., 1978; Stumm \& Morgan, 1996; Pentecost, 2005) and their effects on the SIc values (Fig. 10D) and PWP rates (Fig. 10H), which usually present higher values in the warm periods. Furthermore, diffusion between the solid-water and air-water interfaces is also dependent on temperature, and increases if temperatures increase (Chen et al., 2004; Kano et al., 2007).

However, seasonal changes in temperature, day duration and insolation produce variations in the abundance and growth rate of flora and bacteria, thus causing differences: (i) in the areas provided by such substrates for calcite precipitation; and (ii) in the intensity and type of biological activity and its concomitant effects on calcite precipitation through $\mathrm{CO}_{2}$ uptake (Arp et al., 2001; Pentecost, 2005). Accordingly, in the study case, the deposits of facies A, C and D involved greater masses (thicker deposition) of in situ coated flora and bacteria (for example, cyanobacteria) during the warm periods than during the cool periods. In fact, the six-month deposition rates have very significant correlation with the insolation values $(r=0 \cdot 70$ for facies A; Fig. 16; Table 5) which might be indicative, at least in part, of a biological influence. Thus, the physiological activity of flora and bacteria is one of the factors that influences seasonal variations in tufa depositional rates, although its contribution is difficult to estimate (Shiraishi et al., 2008, 2010).

The correlation between the six-month deposition rates and temperature (and insolation), although significant, is far from perfect (from $r=0.57$ up to $r=0.66$ with air temperature, depending on the group of data considered; see text above; Fig. 16; Table 5). The erosional events and occasional changes in fluvial hydrochemistry occurring during some periods may have had effects that were opposite to those of seasonal temperature changes on tufa deposition. These phenomena may also be the causes of some exceptions to the six-month deposition rate pattern.

The comparison of the six-month deposition rates of each group of periods (i.e. the group of warm periods and the group of cool periods) with air and water temperature variations for each period showed no significant correlation (Fig. 16; Table 5). Thus, it can be inferred that small intraseasonal variations of temperature alone do not explain the variations in the depo- sition rates within each group. Such relations might also be influenced, at least partially, by the effects of erosion on the deposition rates, which were more intense in the warm periods and were related to high discharge events. In addition, the changes in river hydrochemistry caused by abnormally high precipitation and, hence, high discharge caused a strong dilution, producing decreases in the concentrations of all of the chemical components for a short time span, yielding less favourable conditions for calcite precipitation (Zhang et al., 2012); their negative effects are more noticeable in cool than in warm periods because of the already smaller chemical concentration in cool periods (for example, note that water samples of January 2010 are set apart in Fig. 14). Moreover, these short changes in chemical concentration commonly coincided with physical erosion processes.

For a few cool periods, higher than normal deposition rate values (for example, periods 2002 to 2003 and 2003 to 2004) coincide with higher mean air temperature in some months (October, November and/or March; Fig. 16C, D and E) compared with the same months in other periods (ca 2 to $3^{\circ} \mathrm{C}$ higher). However, other cool periods (for example, 2006 to 2007 and 2009 to 2010) with high mean temperatures in those months recorded very small deposition. In January 2010, the high discharge produced by abnormally high precipitation (Figs 2 and 3) provoked strong erosion and dilution of the chemical composition of water (Fig. 14A), resulting in very small deposition in Cool 2009-10. On the contrary, the largest deposition rate was recorded in Cool 2010-11 (8.10 mm), with mean autumn and winter temperatures similar to the mean; tablets from that period did not record negative values, and no other evidence of erosion was observed in the field.

The low rates in some warm periods (lower than mean values) were mostly associated with erosion events occurring in May/June which, in most cases, coincided with high discharge episodes produced by rain storms, for instance during Warm 2003, 2004 and 2011 (Figs 2 and 3). In fact, the correlation between the deposition rates for warm periods and water discharge is negative ( $r=-0 \cdot 60$; Fig. 16A, D and E; Table 5). Some tablets from these periods had negative and/or lower than average deposition rates, in both cases related to erosional features that were recognized in the field and/or on tablets (Fig. 7). Indeed, the correlation between the deposition 
rates in warm periods and precipitation is also negative $(r=-0.59)$, which may account for both erosion and chemical dilution in some periods. For instance, the small deposition in Warm 2008 indeed coincided with a dilution of the chemical concentration of the river water (detected in the June sampling; Appendix 1), which is associated with the highest precipitation in spring $2008(272.6 \mathrm{~mm})$ compared with that of other springs (mean spring precipitation: $152 \mathrm{~mm}$; Fig. 2).

The exceptions to the six-month deposition rate patterns were therefore related to strong physical erosion occurring mostly in May/June and, in some cases, in November and January. In most cases, the erosion was caused by high discharge events (provoked by heavy rain storms) that, in turn, provoked the dilution of the river water for short time spans. Occasionally, high mean seasonal precipitation also led to water dilution, which did not favour calcite precipitation. The effect of small variations in temperature among the cool periods and among the warm periods was obliterated by such phenomena (Fig. 16). The causes of high deposition in Cool 2010-11 could be linked to the apparent absence of erosion that paralleled the almost steady water discharge over the six months.

A comparison of six-month and yearly deposition rates with other parameters, such as sun spots and solar irradiance did not yield any significant relations, nor did the NAO (North Atlantic Oscillation) index (Table 5). Wang et al. (2010), Cattiaux et al. (2010) and Ouzeau et al. (2011), among others, related the low temperatures recorded during winter 2009 to 2010 in the northern hemisphere to an exceptionally negative NAO index (-4.64; NAO data from Hurrell, 1995; http://climatedataguide.ucar.edu/ guidance/hurrell-north-atlantic-oscillation-naoindex-station-based). In the Iberian Peninsula, the outstanding feature of that winter was the high precipitation in the south and west (VicenteSerrano et al., 2010). In the River Piedra, the smallest deposition rates $(<1 \mathrm{~mm})$ corresponded to Cool 2000-01 and 2009-10; the former also had a low NAO in the winter, but it was not exceptionally negative (-1.90). Very different mean winter temperatures were recorded in Cool $2000-01\left(8 \cdot 5^{\circ} \mathrm{C}\right)$ and in Cool $2009-10\left(5 \cdot 6^{\circ} \mathrm{C}\right)$ in the studied area, although the mean six-month temperatures and insolation were similar during both periods (Fig. 16); higher precipitation and river discharge occurred in January 2010 (Figs 2 and 3) causing erosion in the river bed and dilution in the river water (Fig. 14). However, despite these apparent coincidences, the correlation between the six-month deposition rates and the NAO index (six-month and winter) is almost non-existent (Table 5). In fact, Cool 2010-11 recorded the highest deposition rates and had a negative NAO in the winter $(-1.57)$, but the discharge was low and very stable over time (Figs 2 and 16).

To summarize, temperature was the main factor leading the variations in the deposition rate by means of its influence on the physico-chemical and biological processes over time. Other variables involved in tufa sedimentation could interact in the same or opposite manner to temperature on seasonal tufa deposition rates. Therefore, a long-time series of data is necessary to detect patterns in deposition rates and their causes. The reversal of the seasonal thickness patterns can be an indicator of erosion and of changes in hydrological conditions (for example, river discharge). Erosion is a common process that may obliterate the influence of climaterelated parameters, such as temperature, insolation, sun spots and NAO, on tufa deposition rates. This issue should be considered in palaeoclimatic studies based on the fluvial tufa record. The geochemical composition (for example, stable isotopes) would help discern whether such seasonal thickness variations are linked to temperature variations or are solely caused by erosion (Arenas et al., 2010).

\section{CONCLUSIONS}

The sedimentological and hydrochemical parameters associated with tufa formation were monitored along the River Piedra once every six months from 1999 to 2012, at a total of 24 sites that represent five main subenvironments in which seven sedimentary facies were characterized. There are multiple highlights of this study:

1 Water flow conditions control the deposition rates of fluvial carbonate facies, mainly through $\mathrm{CO}_{2}$ outgassing which is greater in shallow areas of fast-flowing water. Accordingly, facies A (stromatolites) and facies C (spongy, moss and alga tufa) record the largest rates, whereas facies B (loose tufa sediment formed in slow-flowing water) and facies $\mathrm{D}$ (formed in spray areas) have much thinner deposition. In contrast, the small tufa deposition of facies E (poorly calcite-coated 
mosses and algae and detrital sediment) is related to the greater $\mathrm{pCO}_{2}$ of water caused by nearby spring inputs. Local erosional processes primarily affected facies B and C. In contrast, stromatolites are the facies least affected by erosion, and thus are likely to preserve complete information in the sedimentary record.

2 The dominant discharge of the main upstream spring $\mathrm{S} 2$ conditions the $\mathrm{HCO}_{3}-\mathrm{SO}_{4}$ $\mathrm{Ca}$ character of the river water. The temperature and chemical characteristics of this ground water input remain remarkably constant through time. From this upstream area, overall decreasing trends in alkalinity, dissolved Ca and TDIC values occur along the studied stretch, in both the warm and cool periods, as a result of calcite precipitation.

3 Tufa deposition is detected ca $7 \mathrm{~km}$ downstream of spring S2, and it increases downstream, primarily within the Natural Park, coinciding with the increase in slope of the river bed. Parallel variations of SIc (calcite saturation index) and PWP (Plummer, Wigley, Parkhurst) values occur. Such an evolution of tufa deposition through space is determined by the amount of $\mathrm{CO}_{2}$ dissolved in the water at each monitored site, which is controlled by two factors: (i) the influence of spring water inputs (their composition and proportion of mixing with respect to river water) upstream and downstream of the Natural Park; and (ii) changes in slope along the river course.

4 The pattern of larger deposition in warm periods (spring and summer seasons) than in cool periods (autumn and winter seasons), with mean values of $5.08 \mathrm{~mm}$ and $2.77 \mathrm{~mm}$, is linked mainly to temperature variations, which cause seasonal changes in the intensity of physicochemical and biological processes. Other seasonal parameters (for example, day duration and insolation) may also contribute to such differences. This deposition pattern is independent of depositional settings and spatial distribution of the studied sites. The seasonal variations of PWP rates of the river water also indicate that temperature is the main factor that controls seasonal deposition rates.

5 Exceptions to the six-month deposition rate pattern are caused by physical erosion, mostly linked to high water discharge (for example, caused by abnormal high precipitation) which, in turn, may lead to the dilution of the river water for short time spans. The reversal of the seasonal deposition rate pattern may thus be an indicator of erosion and of exceptional hydrological condi- tions. In any event, a long-time series of data is necessary to detect the reliable patterns of present-day sedimentation and infer their causes.

6 The correlation between the six-month deposition rates and the NAO index (six-month and winter) and sun spots is almost non-existent. The effects of erosion and hydrochemical changes may overpower the influence of parameters such as temperature, insolation, sun spots or NAO on tufa sedimentation. This issue should be considered in palaeoclimatic analyses based on the ancient tufa record, in particular in semi-arid conditions.

\section{ACKOWLEDGEMENTS}

This study was funded by projects REN2002-3575/ CLI, CGL2006-05063/BTE and CGL2009-09216/ CLI of the Spanish Government and European Regional Funds. This study forms part of the activities of the Continental Sedimentary Basins Analysis and PaleoQ Groups (Aragón Government and University of Zaragoza). We are grateful to the personnel of the Servicio de preparación rocas y materiales duros and SEM of the University of Zaragoza for their technical help. We thank the management and staff of the Monasterio de Piedra Natural Park for allowing and facilitating the field work. The comments of the editors of the volume and reviewers greatly contributed to improve the manuscript.

\section{REFERENCES}

Andrews, J.E. (2006) Palaeoclimatic records from stable isotopes in riverine tufas: synthesis and review. Earth-Sci. Rev., 75, 85-104.

Arenas, C., Auqué, L.F., Elías, Mª J., Longares, L.A., Osácar, M.C., Pardo, G., Peña, J.L., Sancho, C. and VázquezUrbez, M. (2004) Depósitos tobáceos actuales y fósiles del río Piedra (provincia de Zaragoza). In: Geo-Guías 1. Itinerarios Geológicos por Aragón (Eds F. Colombo, C.L. Liesa, G. Meléndez, A. Pocoví, C. Sancho and A.R. Soria), pp. 11-32. Sociedad Geológica de España, Zaragoza, Spain.

Arenas, C., Osácar, C., Sancho, C., Vázquez-Urbez, M., Auqué, L. and Pardo, G. (2010) Seasonal record from recent fluvial tufa deposits (Monasterio de Piedra, NE Spain): sedimentological and stable isotope data. In: Tufas and Speleothems: Unravelling the Microbial and Physical Controls (Eds H.M. Pedley and M. Rogerson), pp. 119-142. Geological Society, London.

Arp, G., Wedemeyer, N. and Reitner, J. (2001) Fluvial tufa formation in a hard-water creek (Deinschwanger Bach, Franconian Alb, Germany). Facies, 44, 1-22.

Arp, G., Bissett, A., Brinkmann, N., Cousin, S., de Beer, D., Friedl, T., Mohr, K.I., Neu, T.R., Reimer, A., Shiraishi, F., 
Stackebrandt, E. and Zippel, B. (2010) Tufa-forming biofilms of German karstwater streams: microorganisms, exopolymers, hydrochemistry and calcification. In: Tufas and Speleothems: unravelling the Microbial and Physical Controls (Eds H.M. Pedley and M. Rogerson), pp. 83-118. Geological Society, London.

Auqué, L., Arenas, C., Osácar, C., Pardo, G., Sancho, C. and Vázquez-Urbez, M. (2013) Tufa sedimentation in changing hydrological conditions: the River Mesa (Spain). Geol. Acta, 11, 85-102.

Ball, J.W. and Nordstrom, D.K. (2001) User's manual for WATEQ4F, with revised thermodynamic data base and test cases for calculating speciation of major, trace, and redox elements in natural waters. U.S. Geological Survey, Open File Report 91-183.

Beraldi-Campesi, H., Arenas-Abad, C., Garcia-Pichel, F., Arellano-Aguilar, O., Auqué, L., Vázquez-Urbez, M., Sancho, C., Osácar, C. and Ruiz-Velasco, S. (2012) Benthic bacterial diversity from freshwater tufas of the Iberian Range (Spain). FEMS Microbiol. Ecol., 80, 363-379. doi: 10.1111/j.1574-6941.2012.01303.x

Brasier, A.T., Andrews, J.E., Marca-Bell, A.D. and Dennis, P.F. (2010) Depositional continuity of seasonally laminated tufas: Implications for $\delta^{18} \mathrm{O}$ based palaeotemperatures. Global Planet. Change, 71, 160-167. doi:10.1016/j.gloplacha.2009.03.022

Cattiaux, J., Vautard, R., Cassou, C., Yiou, P., MassonDelmotte, V. and Codron, F. (2010) Winter 2010 in Europe: A cold extreme in a warming climate. Geophys. Res. Lett., 37, L20704. doi:10.1029/2010GL044613

Chen, J., Zhang, D. D., Shijie, W., Tangfu, X. and Ronggui, H. (2004) Factors controlling tufa deposition in natural waters at waterfall sites. Sed. Geol., 166, 353-366.

Dandurand, J.L., Gout, R., Hoefs, J., Menschel, G., Schott, J. and Usdowski, E. (1982) Kinetically controlled variations of major components and carbon and oxygen isotopes in a calcite-precipitating spring. Chem. Geol., 36, 299-315.

Davis, J.C. (2002). Statistics and Data Analysis in Geology, 3rd Edn. John Wiley and Sons, New York, 638 pp.

Dreybrodt, W. (1981) The kinetics of calcite precipitation from thin films of calcareous solutions and growth of speleothems: revisited. Chem. Geol., 32, 237-245.

Dreybrodt, W. and Buhmann, D. (1991) A mass transfer model for dissolution and precipitation of calcite from solutions in turbulent motion. Chem. Geol., 90, 107-122.

Dreybrodt, W., Buhmann, D., Michaelis, J. and Usdowski, E. (1992) Geochemically controlled calcite precipitation by CO2 outgassing: Field measurements of precipitation rates in comparison to theoretical predictions. Chem. Geol., 97, 285-294.

Drysdale, R. and Gillieson, D. (1997) Micro-erosion meter measurements of travertine deposition rates: a case study from Louie Creek, northwest Queensland, Australia. Earth Surf. Proc. Land., 22, 1037-1051.

Drysdale, R.N., Taylor, M.P. and Ihlenfeld, C. (2002) Factors controlling the chemical evolution of travertine-depositing rivers of the Barkly karst, Northern Australia. Hydrol. Process., 16, 2941-2962.

Emeis, K.C., Richnow, H.H. and Kempe, S. (1987) Travertine formation in Plitvice National Park, Yugoslavia: chemical versus biological control. J. Sed. Petrol., 34, 595-609.

Ford, T.D. (1989) Tufa: a freshwater limestone. Geol. Today, 5, 60-63.
Gabaldón, V. (coord.), Lendínez, A., Ferreiro, E., Ruiz, V., López de Alda, F., Valverde, L., Lago San José, M., Meléndez, A., Pardo, G., Ardevol, L., Villena, J., Pérez, A., González, A., Hernández, A., Álvaro, M., Leal, M.C., Aguilar Tomás, M., Gómez, J.J. and Carls, P. (1991). Mapa Geológico de España, Sheet n. 40 (Daroca), 1:200.000. Memoir and cartography. Instituto Geológico y GeoMinero de España, Madrid, 239 pp.

Gradziński, M. (2010) Factors controlling growth of modern tufa: results of a field experiment. In: Tufas and Speleothems: Unravelling the Microbial and Physical Controls (Eds M. Pedley and M. Rogerson), pp. 143-191. Geological Society, London.

Hammer, Ø. (2010) PAST. PAleontological STatistics, Version 2.03. Reference manual. Natural History Museum. University of Oslo, Oslo, Norway, 204 pp. Available at http://folk.uio.no/ohammer/past/index.html

Hori, M., Kawai, T., Matsuoka, J. and Kano, A. (2009) Intraannual perturbations of stable isotopes in tufas: Effects of hydrological processes. Geochim. Cosmochim. Acta, 73, 1684-1695. doi:10.1016/j.gca.2008.12.024

Hurrell, J. (1995) NAO Index Data provided by the Climate Analysis Section, NCAR, Boulder, USA. http:// climatedataguide.ucar.edu/guidance/hurrell-north-atlanticoscillation-nao-index-station-based. Updated regularly.

Jacobson, R.L. and Usdowski, E. (1975) Geochemical controls on a calcite precipitating spring. Contrib. Miner. Petrol., 51, 65-74.

Kano, A., Matsuoka, J., Kojo, T. and Fujii, H. (2003) Origin of annual laminations in tufa deposits, southwest Japan. Palaeogeogr. Palaeoclimatol. Palaeoecol., 191, 243-262.

Kano, A., Hagiwara, R., Kawa, T., Hori, M. and Matsuoka, J. (2007) Climatic conditions and hydrological change recorded in a high-resolution stable-isotope profile of a recent laminated tufa on a subtropical island, southern Japan. J. Sed. Res., 77, 59-67.

Kaufmann, G. and Dreybrodt, W. (2007) Calcite dissolution kinetics in the system CaCO3-H2O-CO2 at high undersaturation. Geochim. Cosmochim. Acta, 71, 13981410. doi:10.1016/j.gca.2006.10.024

Kawai, T., Kano, A., Matsuoka, J. and Ihara, T. (2006) Seasonal variation in water chemistry and depositional processes in a tufa-bearing stream in SW-Japan, based on 5 years of monthly observations. Chem. Geol., 232, 33-53.

Kawai, T., Kano, A. and Hori, M. (2009) Geochemical and hydrological controls on biannual lamination of tufa deposits. Sed. Geol., 213, 41-50. doi:10.1016/j.sedgeo. 2008.11.003.

Liu, Z., Svensson, U., Dreybrodt, W., Yuan, D. and Buhmann, D. (1995) Hydrodynamic control of inorganic calcite precipitation in Huanglong Ravine, China: field measurement and theoretical prediction of deposition rates. Geochim. Cosmochim. Acta, 59, 3087-3097. doi: 10. 1016/0016-7037(95)00198-9

Lojen, S., Dolenec, T., Vokal, B., Cukrov, N., Mihelčić, G. and Papesch, W. (2004) C and O stable isotope variability in recent freshwater carbonates (River Krka, Croatia). Sedimentology, 51, 361-375.

Lorah, M.M. and Herman, J.S. (1988) The chemical evolution of a travertine depositing stream: geochemical processes and mass transfer reactions. Water Resour. Res., 24, 1541-1552.

Malusa, J., Overby, S.T. and Parnell, R.A. (2003) Potential for travertine formation: Fossil Creek, Arizona. Appl. Geochem., 18, 1081-1093. 
Manzo, E., Perri, E. and Tucker, M.E. (2012) Carbonate deposition in a fluvial tufa system: processes and products (Corvino Valley - southern Italy). Sedimentology, 59, 553-577. doi: 10.1111/j.1365-3091.2011.01266.x

Merz-Preiß, M. and Riding, R. (1999) Cyanobacterial tufa calcification in two freshwater streams: ambient environment, chemical thresholds and biological processes. Sed. Geol., 126, 103-124.

Osácar, C., Arenas, C., Vázquez-Urbez, M., Sancho, C., Auqué, L.F. and Pardo, G. (2013). Environmental factors controlling the $\delta^{13} \mathrm{C}$ and $\delta^{18} \mathrm{O}$ variations of recent fluvial tufas: a 12-year record from the Monasterio de Piedra Natural Park (NE Iberian Peninsula). J. Sed. Res., 83. doi: 10.2110/jsr.2013.27

Ouzeau, G., Cattiaux, J., Douville, H., Ribes, A. and SaintMartin, D. (2011) European cold winter 2009-2010: How unusual in the instrumental record and how reproducible in the ARPEGE - Climate model? Geophys. Res. Lett., 38, L11706. doi:10.1029/2011GL047667, 2011

Parkhurst, D.L. and Appelo, C.A.J. (1999) User's Guide to PHREEQC (Version 2), a computer program for speciation, batch-reaction, one-dimensional transport, and inverse geochemical calculations. Water Resources Research Investigations, Report 99-4259, pp 1-312

Pedley, H.M. (2000) Ambient temperature freshwater microbial tufas. In: Microbial Sediments (Eds R. Riding and S.M. Awramik), pp. 179-186, Springer, Berlin.

Pedley, H.M. and Rogerson, M. (2010) In vitro investigations of the impact of different temperature and flow velocity conditions on tufa microfabric. In: Tufas and Speleothems: Unravelling the Microbial and Physical Controls (Eds H.M. Pedley and M. Rogerson), pp. 193-210. Geological Society, London.

Pedley, H.M., Rogerson, M. and Middleton, R. (2009) Freshwater calcite precipitates from in vitro mesocosm flume experiments: a case for biomediation of tufas. Sedimentology, 56, 511-527. doi: 10.1111/j.1365-3091. 2008.00983.x

Pentecost, A. (1978) Blue-green algae and freshwater carbonate deposits. Proc. Roy. Soc. London B, 200, 43-61.

Pentecost, A. (2005) Travertine. Springer-Verlag, Berlin. pp $1-445$.

Plummer, L.N., Wigley, T.M.L. and Parkhurst, D.L. (1978) The kinetics of calcite dissolution in CO2-water system at $5^{\circ}$ to $60^{\circ} \mathrm{C}$ and 0.0 to $1.0 \mathrm{~atm}$ CO2. Am. J. Sci., 278, 179216.

Sancho, C., Arenas, C., Pardo, G., Vázquez-Urbez, M., Hellstrom, J., Ortiz, J.E., Rhodes, E.J., Osácar, C. and Auqué, L. (2010) Ensayo cronológico de las tobas cuaternarias del río Piedra (Cordillera Ibérica). Geogaceta, 48, 31-34.

Santos, F., Peña, A., Nogales, B., Soria-Soria, E., García del Cura, M.A., González-Martín, J.A. and Antón, J. (2010) Bacterial diversity in dry modern freshwater stromatolites from Ruidera Pools Natural Park, Spain. Syst. Appl. Microbiol., 33, 209-221. doi:10.1016/j.syapm.2010.02.006.

Servicio Geológico de Obras Públicas (1990) Estudio de los recursos hidráulicos subterráneos de los acuíferos relacionados con la provincia de Zaragoza. Unidad hidrogeológica $n^{\circ}$ 43. Sierra del Solorio. Informe interno, Madrid, $210 \mathrm{pp}$.
Shiraishi, F., Reimer, A., Bisset, A., de Beer, D. and Arp, G. (2008) Microbial effects on biofilm calcification, ambient water chemistry and stable isotope records in a highly supersaturated setting (Westerhöfer Bach, Germany). Palaeogeogr. Palaeoclimatol. Palaeoecol., 262, 91-106.

Shiraishi, F., Okumura, T., Takahashi, Y. and Kano, A. (2010) Influence of microbial photosynthesis on tufa stromatolite formation and ambient water chemistry, SW Japan. Geochim. Cosmochim. Acta, 74, 5289-5304.

Stumm, W. and Morgan, J.J. (1996) Aquatic chemistry. Wiley, New York. 1022 pp.

Suarez, D.L. (1983) Calcite supersaturation and precipitation kinetics in lower Colorado River, All-American canal and east highland canal. Water Resour. Res., 19, 653-661.

Vázquez-Urbez, M., Arenas, C., Sancho, C., Osácar, C., Auqué, L. and Pardo, G. (2010) Factors controlling presentday tufa dynamics in the Monaterio de Piedra Natural Park (Iberian Range, Spain): depositional environmental settings, sedimentation rates and hydrochemistry. Int. J. Earth Sci. (Geol. Rundsch.), 99, 1027-1049. doi: 10.1007/s00531-0090444-2.

Vázquez-Urbez, M., Arenas, C., Sancho, C., Auqué, L., Osácar, C. and Pardo, G. (2011) Quaternary and presentday tufa systems of the Piedra and Añamaza rivers (Iberian Range, Spain). In: Geo-Guías, 8. Post-meeting Field Trips Guidebook, 28th IAS meeting (Eds C. Arenas, L. Pomar and F. Colombo), Sociedad Geológica de España, Zaragoza, Spain, pp. 241-274.

Vázquez-Urbez, M., Arenas, C. and Pardo, G. (2012) A sedimentary facies model for stepped, fluvial tufa systems in the Iberian Range (Spain): the Quaternary Piedra and Mesa valleys. Sedimentology, 59, 502-526. doi: 10.1111/j. 1365-3091.2011.01262.x

Vicente-Serrano, S.M., Trigo, R.M., López-Moreno, J.I., Liberato, M.L.R., Lorenzo-Lacruz, J., Beguería, S., MoránTejeda, E. and El Kenawy, A. (2010) Extreme winter precipitation in the Iberian Peninsula in 2010: anomalies, driving mecanisms and future projections. Clim. Res., 46, 51-65. doi: 10.3354/cr00977.

Wang, C., Liu, H. and Lee, S.K. (2010) The record-breaking cold temperatures during the winter of 2009/2010 in the Northern Hemisphere. Atmos. Sci. Let., 11, 161-168. doi: 10.1002/asl.278.

Yoshimura, K., Liu, Z., Cao, J., Yuan, D., Inokura, Y. and Noto, M. (2004) Deep source CO2 in natural waters and its role in extensive tufa deposition in the Huanglong Ravines, Sichuan, China. Chem. Geol., 205, 141-153.

Zhang, D.D., Zhang, Y., Zhu, A. and Cheng, X. (2001) Physical mechanisms of river waterfall tufa (travertine) formation. J. Sed. Res., 71, 205-216. doi: 10.1306/ 061600710205.

Zhang, J., Wang, H., Liu, Z., An, D. and Dreybrodt, W. (2012) Spatial-temporal variations of travertine deposition rates and their controlling factors in Huanglong Ravine, China - A world's heritage site. Appl. Geochem., 27, 211-222. doi:10.1016/j.apgeochem.2011.10.005.

Manuscript received 9 May 2012; revision accepted 7 March 2013 


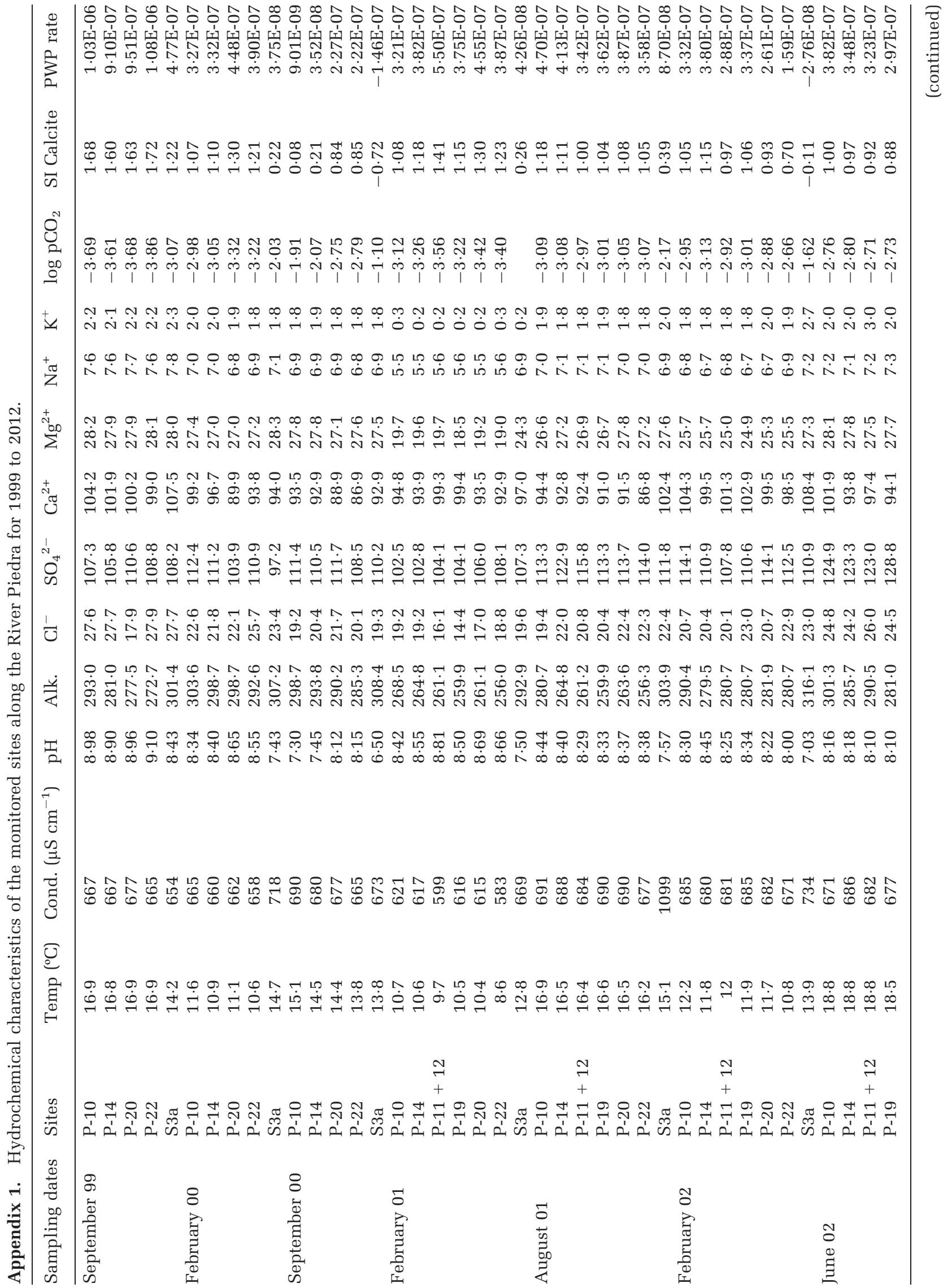

(C) 2013 The Authors. Journal compilation (C) 2013 International Association of Sedimentologists, Sedimentology, 61, 90-132 




(C) 2013 The Authors. Journal compilation (C) 2013 International Association of Sedimentologists, Sedimentology, 61, 90-132 


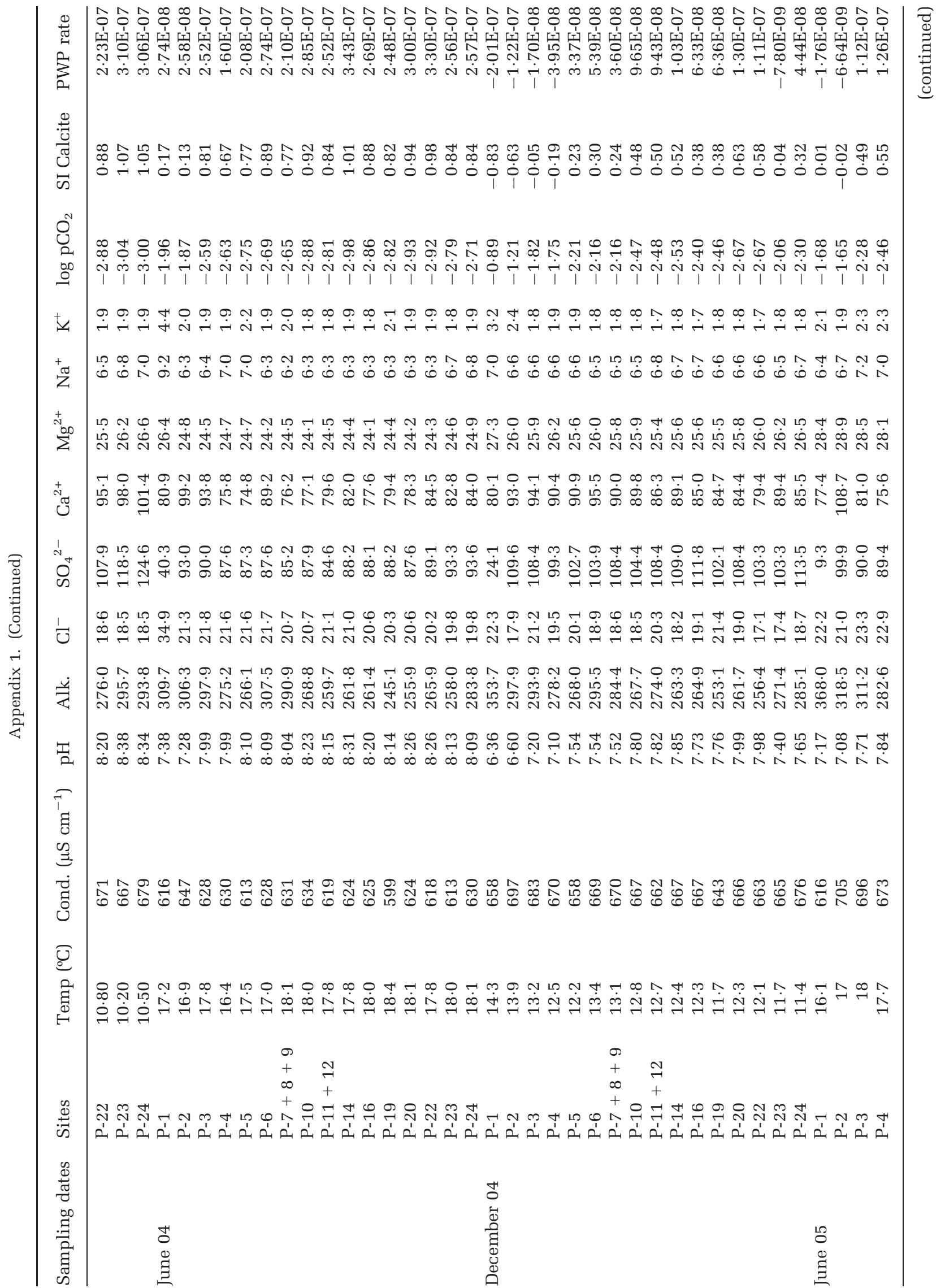

(C) 2013 The Authors. Journal compilation (C) 2013 International Association of Sedimentologists, Sedimentology, 61, 90-132 


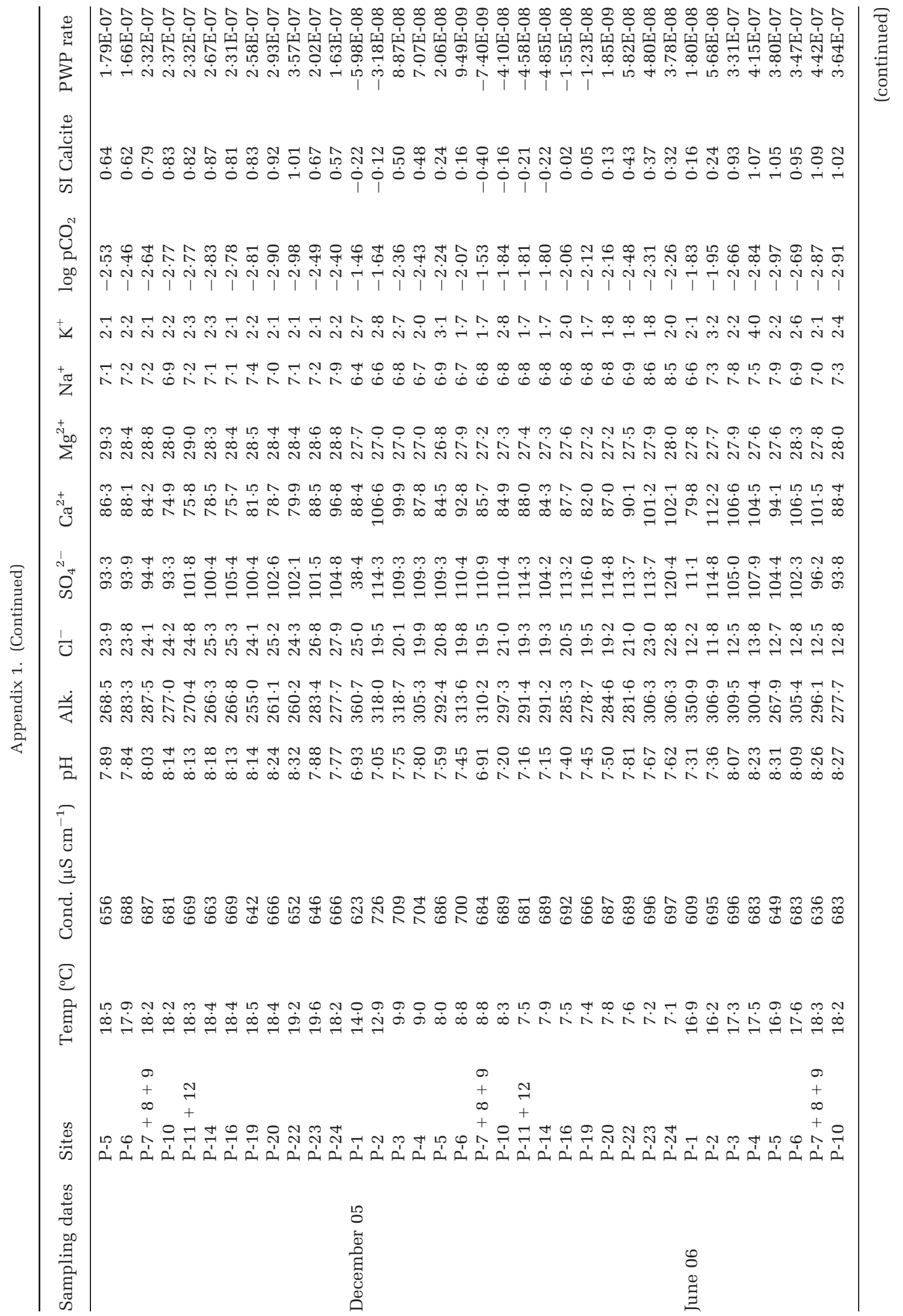

(C) 2013 The Authors. Journal compilation (C) 2013 International Association of Sedimentologists, Sedimentology, 61, 90-132 


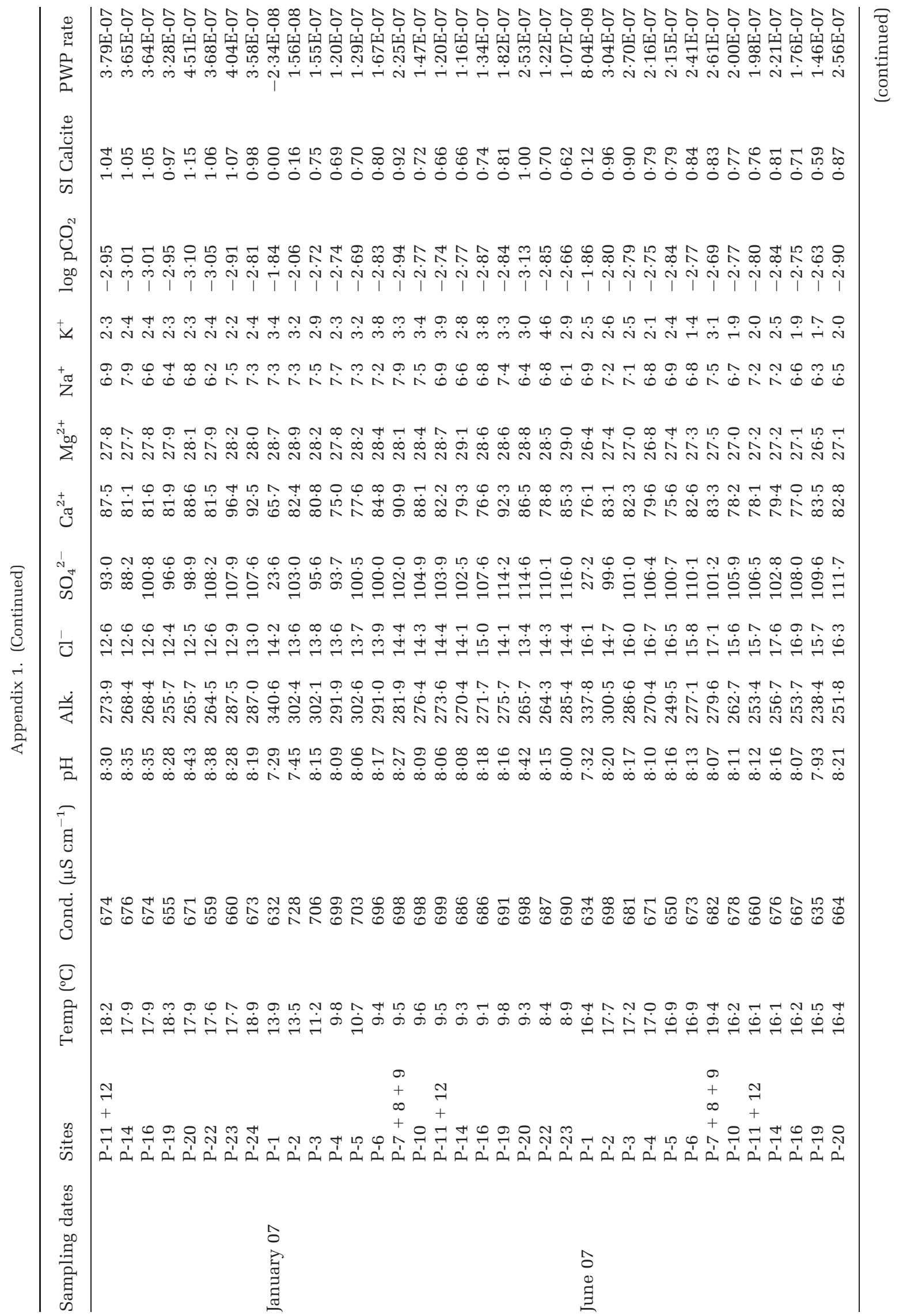

(C) 2013 The Authors. Journal compilation (C) 2013 International Association of Sedimentologists, Sedimentology, 61, 90-132 


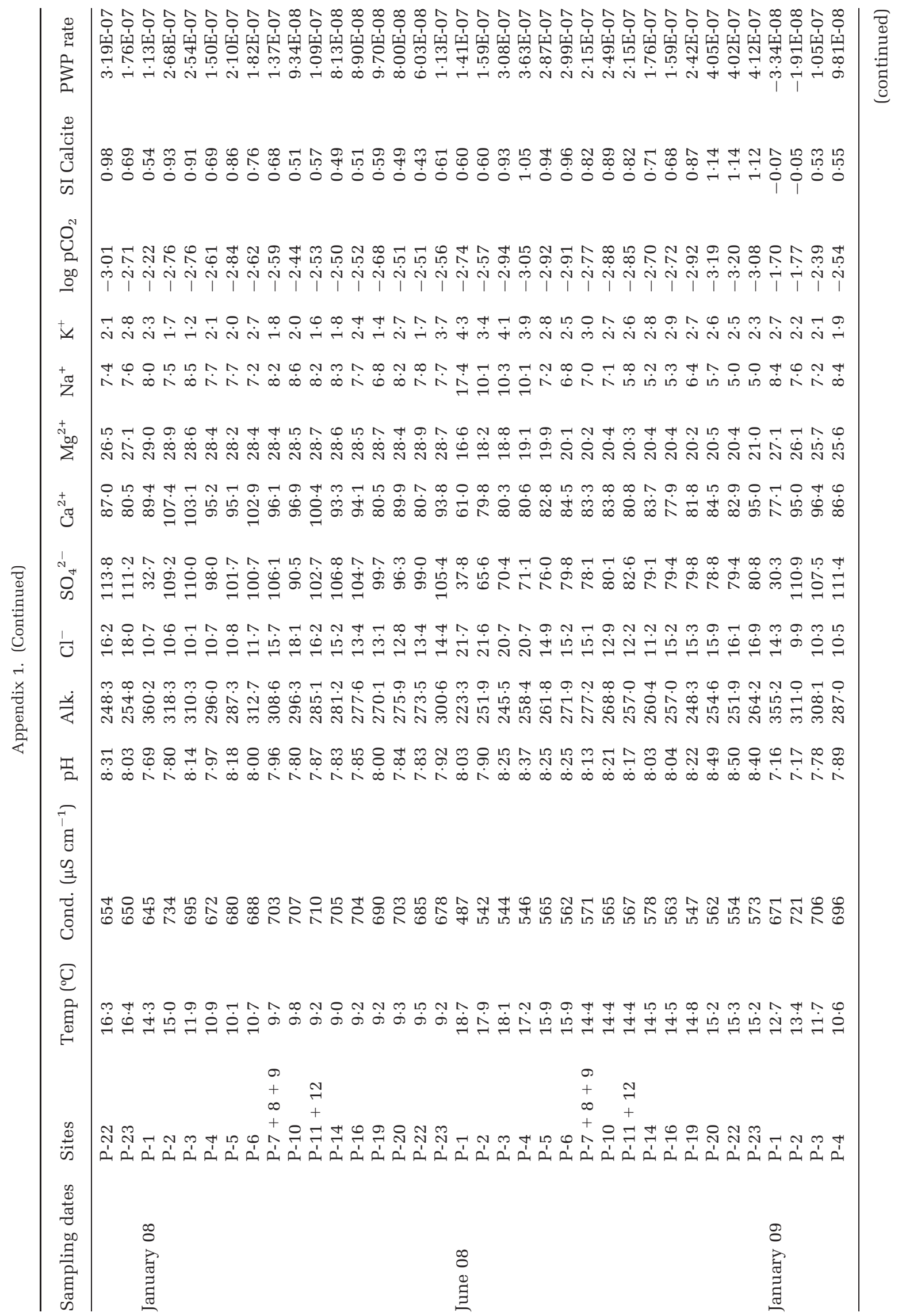

(C) 2013 The Authors. Journal compilation (C) 2013 International Association of Sedimentologists, Sedimentology, 61, 90-132 


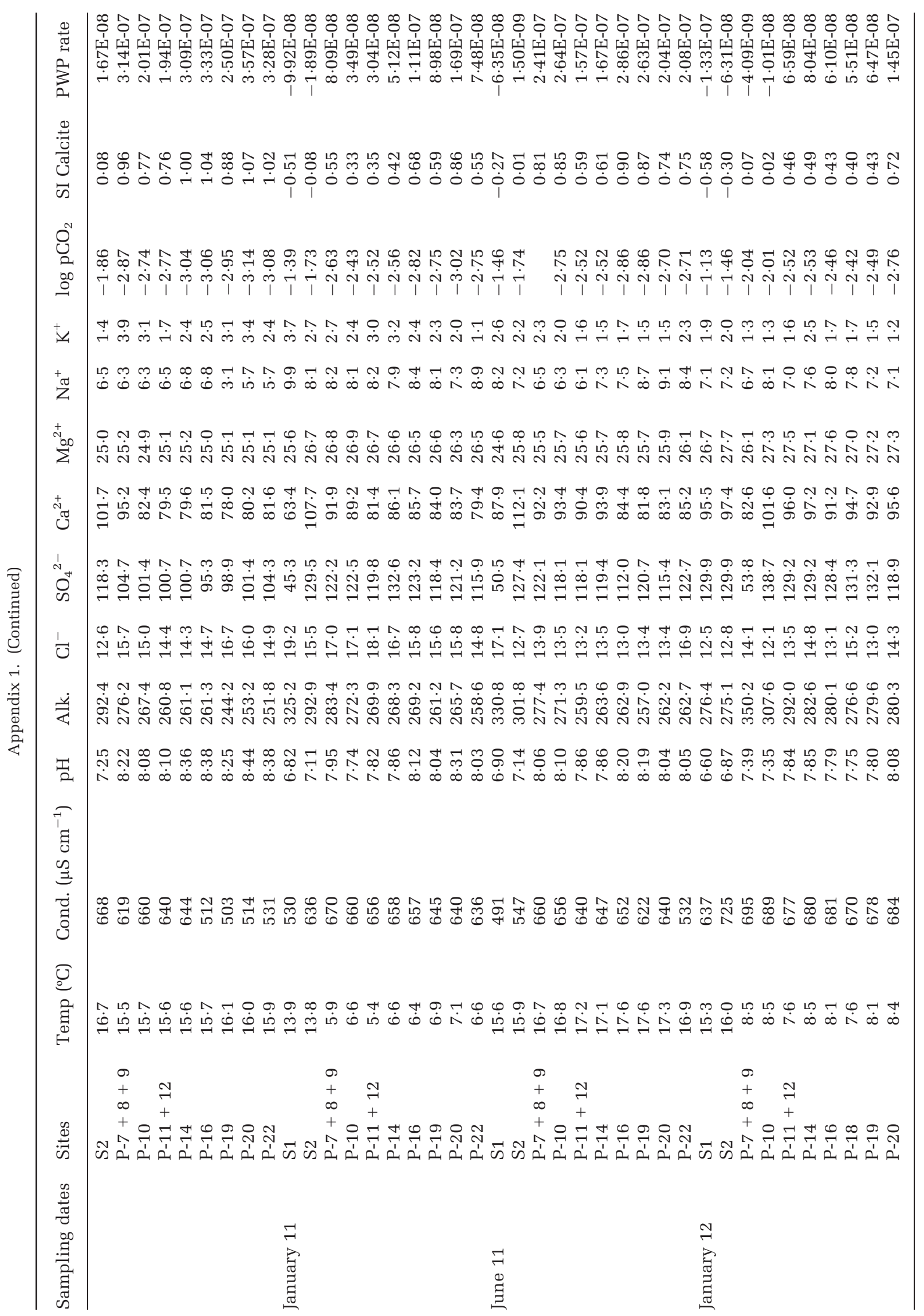

(C) 2013 The Authors. Journal compilation (C) 2013 International Association of Sedimentologists, Sedimentology, 61, 90-132 


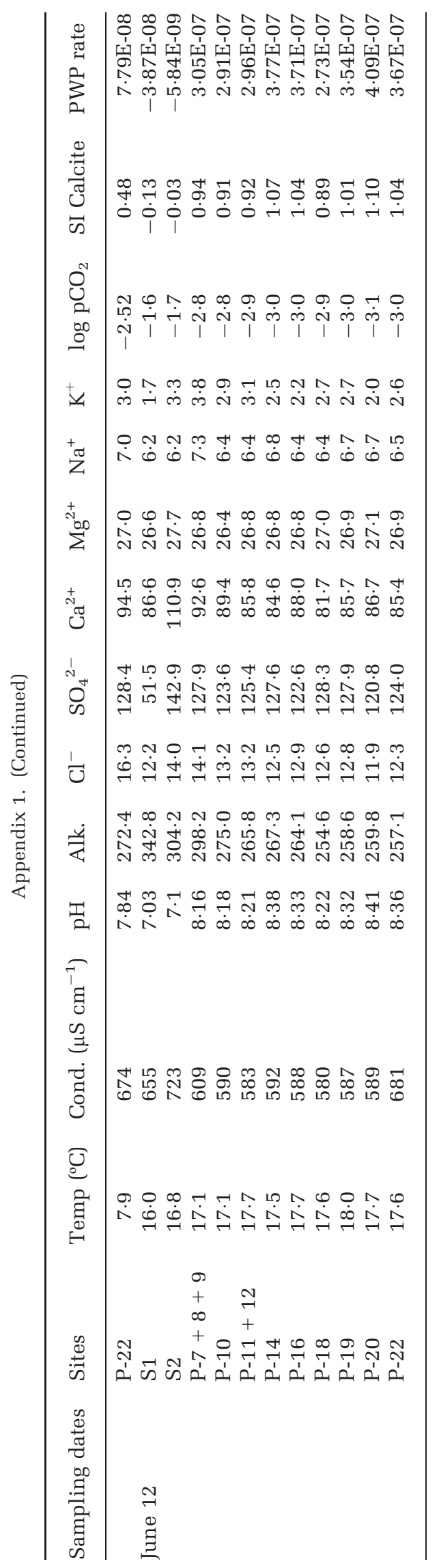

(C) 2013 The Authors. Journal compilation (C) 2013 International Association of Sedimentologists, Sedimentology, 61, 90-132 